NYPL RESEARCH LIBRARIES

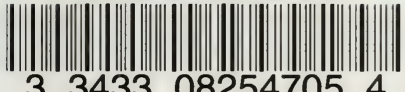

33433082547054 
ISEDOA ISIBRART

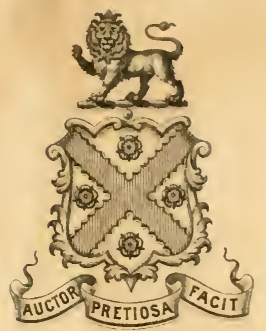

Duturlinti Colletiont. Peesenteotuts 

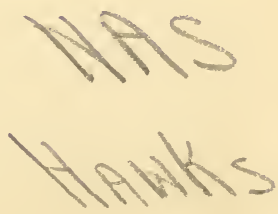
Digitized by the Internet Archive in 2007 with funding from Microsoft Corporation 




PUELL LDRARY

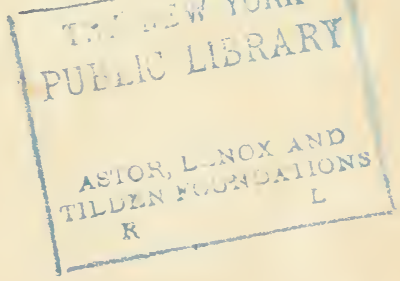




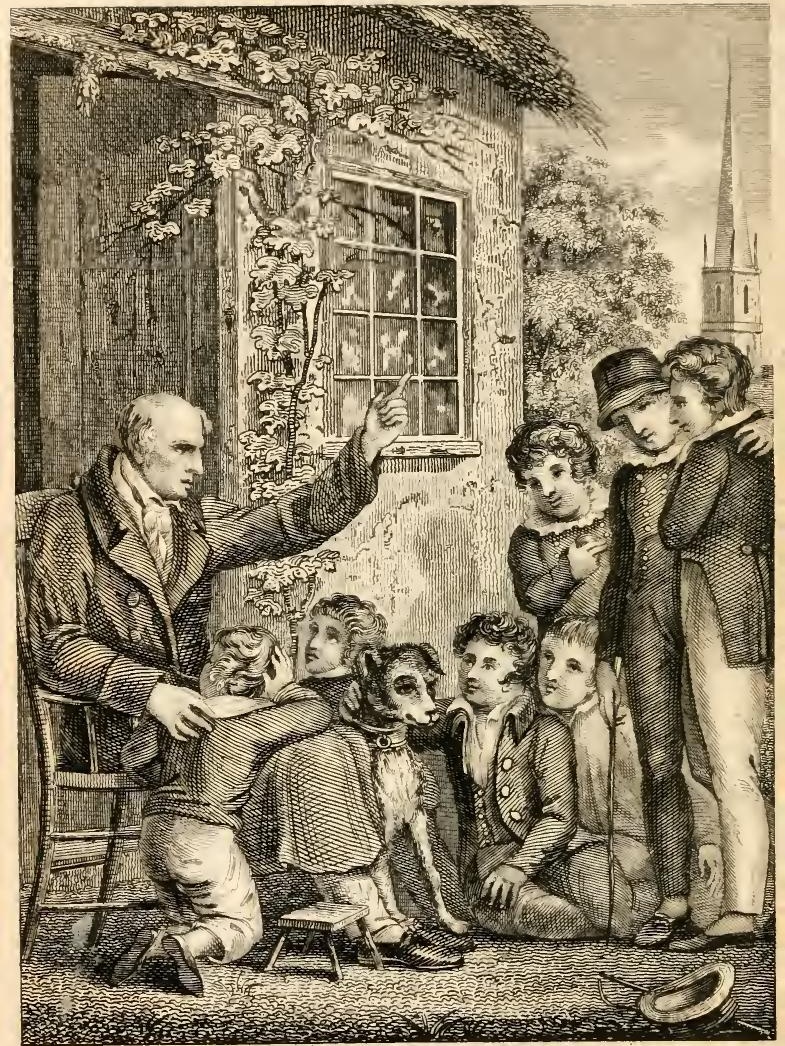

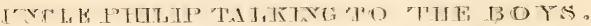





\title{
NATURAL HISTORY;
}

\author{
OR, \\ UNCLE PHILIP'S
}

CONVERSATIONS WITH THE CHILDREN

ABODT

TOOLS AND TRADES

AMONG

INFERIOR ANIMALS.

WITH NUMEROUS ENGRAVINGS.

\section{NEW-YORK :}

PUBLISHED BY HARPER \& BROTBERE,

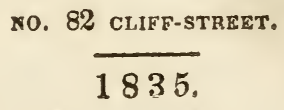


Entered, according to Act of Congress, in the year 1835, BY HARPER \& BROTHERB, In the Clerk's Uffice of the Southern Distnct of New-York.

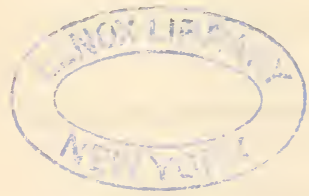




\section{A DVERTISEMENT.}

WE must tell our little readers something about this number of their Library. It was sent to us by a very kind old uncle of ours, who, when we were young, was so much from home, visiting various places in the world, that we do not remember seeing him very often at that period. At last, the old man, finding that he could not bear fatigue as he had done when young, determined to come home; and we had heard so much about him that we were quite anxious to see him. He came to our house one evening, and appeared rather odd to us; but he was so good-natured, and told us so many curious things, that we soon forgot his odd appearance.

The old gentleman brought home with him a very large number of books, and a great many strange things which he had gathered in his travels, such as stones, and dried insects, and leaves, and flowers, and stuffed birds, and animals. He did not stay with us long, but went to the village where he was 
born, and built a small house to which he carried all his books and curiosities, and said that he should spend the rest of his days there.

We sometimes pay him a visit. The last time we were there, we found him talking to several children around him. In the beginning of the book there is a picture of the old gentleman. After you have looked at it, you may read the letter which he sent us, and learn how he came to write this book. Your friends,

The Publishers. 


\section{UNCLE PHILIP'S LETTER.}

\section{My dear Nephews,}

I was very much pleased to receive the numbers of your Library for Boys and Girls which you sent to me. You know I am now an old man, and have travelled a great deal, and seen a great many strange things in the course of my life. I am too old to travel any more, and so I am quietly living in the cottage I built by the side of that pleasant and shady little stream where I played when I was a boy. I read my books, and especially that best of all of them, my Bible; and so am patiently waiting till my Heavenly Father shall call me to take my last journey; when I hope, for the sake of the blessed Saviour, to go to Him. Sometimes I walk out into the village, and meet the children and have a long talk with them. They all know me; and very often, some of them will come to my house, and ask me to tell them about things which I have seen in my travels or read of in books : and so I spend many happy hours with the little creatures; for you 
know how much I love children. When I had read the books you sent to me, I lent them to the children, who were delighted; and I thought that if I should sometimes write down what we here talked about, it might please the little boys and girls for whom you print your books, and perhaps they might learn something from our conversations which would be useful : and so I determined to send them to you, from time to time, to print, if you pleased.

If you think fit to print what I send, just tell your little readers who I am; an aged and quiet old man, who is very fond of little boys and girls, and wishes them to be wise and good here, and happy hereafter, and that $I$ am your

Uncle Philip.

Newtown, Feb. 1833.

P.S. If you print what I send now, please to print the Preface to Parents, which I also send; in order that they may, by reading it, see what sort of a book Uncle Philip has been making for their dear children, and may be satisfied that it will not harm them to read it. 


\section{PREFACE TO PARENTS.}

THE author of the following book avails himself of the opportunity afforded by its publication, to address a word to those who sustain the delightful and responsible relation of parents.

To such of that class as may honour by a perusal this humble attempt to interest and instruct their offspring, the author need not say that the subject of his book possesses for himself peculiar attractions : it will readily be perceived that he has found a charm in the pursuits of the naturalist. The votary of a favourite science would anticipate too much, should he expect every one to partake of the , enthusiasm which is apt to stimulate him; it is wisely and kindly ordered that we shall not all be enthusiasts in the same direction. The author, however, still ventures to hope, that in his subject there is enough to attract, though it may fail to fascinate. He hopes, too, that it will be found not attractive merely, but profitable also to his young countrymen. There are many reasons on which to found such 
a hope. If to entertain reverence for our Maker, to admire and adore his wisdom and goodness in the illustrations of nature, thankfully to acknowledge and duly to improve the superiority which mind confers, be exercises in which a wise parent would desire to train a child,--the study of natural science is admirably adapted to the attainment of these objects. Again, if it be desirable to encourage habits of patient observation, accuracy of investigation, and soundness of thought ; let the volume of nature be opened before the youthful mind. If to learn things be better than to learn words, it is important to place things before the growing intellects of the young. Let it not be supposed that to present matters of science intelligibly to the minds of children is a hopeless task. It requires not learning or maturity of understanding to perceive a fact; it needs only the ordinary senses which God has bestowed alike upon children and their parents. Natural science is emphatically the science of facts; built upon any other foundation it becomes conjecture merely: and he knows but little of the mind of a child who is not aware of the facility with which a fact is impressed upon it. The secret of instructing the young will be found to consist more in the mode of communication than in the nature of the subject. 
As to the style of this work a word may be said; not, of course, for the purpose of disarming criticism (for truly the writer has never supposed his trifle worth the critic's labour or notice), but simply to remark, that the object has been to write for the minds of children; if the book be intelligible to them, the utmost ambition of Uncle Philip will be attained. Truth and plainness were all he sought. The first he believes he has attained; and to determine his success in attempting the last, he turns from the parents, and looks for the decision of the question to the suffrages of the children. He would rather hear the expression of satisfaction from the lips of one intelligent little reader, than receive the words of approbation from many who are elders; the first is testimony derived from experience, the last is but opinion. Children always know better than any one else does what books they understand.

In conclusion, the author owes it to himself to say to the parents of his young countrymen, and to the patrons of the "Boy's and Girl's Library," that what he has written will be found on the side of religion and morals. So far as these important points are concerned, the writer is not ashamed to avow himself a Christian; nor yet does he mean to make it the subject of boasting. In his simple view, Christianity is a very quiet and gentle thing, 
which eschews strife, and promotes practical goodness; and truly can he say, that he has indulged in some of his happiest and, as he trusts, his holiest musings when, in the solitary pursuit of his favourite science,- - to use the language of good old Izaak Walton, that simple-hearted lover of God, and all his works, - " he has looked upon the wonders of nature with admiration, or found some harmless insect to content him, and pass away a little time, without offence to God, or injury to man." 


\section{CONTENTS.}

CONVERSATION I.

ABout a Fly that can work with a Saw and a Rasp, like the Carpenter - - - - - - - - 13

CONVERSATION II.

About Grasshoppers and Bees that bore Holes with a Gimlet 19

CONVERSATION III.

About Animals that are Tailors $\quad$ - $\quad$ - $\quad 27$

CONVERSATION IV.

About the first Paper in the World made by Wasps - $\quad 41$

CONVERSATION V.

A Story about Tom Smith, and of Bees with Brushes and Baskets, and of a Bird with a Chisel, and a Gnat with a

Lancet - • • • - • - - - 53

CONVERSATION VI.

About Animals that can do Mason's Work $\quad$ - $\quad 66$

CONVERSATION VII.

About Animals that throw Dirt with a Spades; and about an Animal with a Hook; and about one that is a Wire-

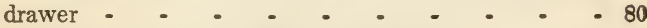

CONVERSATION VIII.

About a Door, with a Hinge and Spring to it, made by a Spicer; and the Difference between GoD's Work and Man's 
CONTERSATION IX.

A Story about a Philosopher and his Kite; and about Ants that hare Awls, and build Cities, and Stairs, and Bridges, and many other Things - . . . . - 104

CONTERSATION $\mathrm{X}$.

More about the white Ants

CONTERSATION XI.

About some other Ants that are rery gaod Masons, and build Walls and Ceilings; and a Story about a very sersitile Ant which seemed to think a little

CONTERSATION XII.

About Ants that go to War, and fight Battles; and about some that are Thieves, and have Slaves

CONVERSATION XIIL.

A Toyage; and an Animal that makes itself into a Ship ; and of an Insect that builds a Boat, and floats about in a Canoe; and of anotber that pumps Water, and wears a Mask; and of a Spider that builds a Raft, and floats upon it

\section{CONVERSATION XIV.}

About an Insect with Tweezers, and another with Pincers; and how a Fly's Foot is made, so as to stick to the Wall 167

$$
\text { CONVERSATION XV. }
$$

How Hats are made; and about Animals that can make Felt like the Hatter

CONVERSATION XVI.

About Birds that are Weavers, and the Politician Bird; a Story about some Philosophers; and what may be leamed from these Conversations 


\section{NATURAL HISTORY.}

\section{CONVERSATION I.}

Uncle Philip tells the Children about a Fly that can work with a Saw and a Rasp, like the Carpenter.

"WeLL, boys, this is a beautiful day. The sun is shining brightly, and the birds are singing, and the insects are flying about, and the grass is green, and every thing appears pleasant, and you feel happy too, and have come, I suppose, to see old Uncle Philip."

"Yes, Uncle Philip, we are tired of playing now, and so we have come to ask you to talk with us, and tell us about some of the curious things you know."

"Well, boys, I will tell you about some very strange things. I will talk to you about B 
animals that know how to work with tools like a man."

"Work with tools, Uncle Philip! That is strange; but we know it is so, if you say so; because you will not tell us any stories but true ones. But where do they get the tools?"

"Ah, boys, "the hand that made them is divine!' 'They get them where we get all that is useful and good,-from Goo. The Bible says that $\mathrm{He}$ ' $i$ s wise in heart, and wonderful in working; and he has made many a poor little insect, and given it tools to work with for its comfort, as good and perfect as any that man can make. Yes, these poor little creatures had tools long before man had. GoD cares for the insects, boys, as well as for us."

"But, Uncle Philip, what sort of tools do you mean? Tell us about them."

"Very well, I will; do you think of some kind of tools that men use : think of the carpenter and his tools, and let us see if we cannot find some of them among the insects."

"Why, the carpenter has a saw. Is there any saw among these little fellows?"

"Yes indeed, there is; and a capital saw 
it is. Now listen, and I will tell you all about it. There is a kind of fly called the saw-fly; it has four wings, and commonly its body is yellow, and its head is black; but the most curious part of it is the saw. : The young ones feed upon the leaves of rose-bushes, and gooseberries, and raspberries, and currants, and several other kinds of bushes; and the old ones always lay their eggs on the branches of these bushes, so that the young ones may have something to eat as soon as they come out. It uses its saw to:make a place in the branch to put its egg in."

"Uncle Philip, what is the saw made of?"

"It is made of something like horn, and is fixed very nicely in a case; it resembles what the cabinet-makers call a tenon-saw more than it does the carpenter's common saw. The tenon-saw is made of a thin plate of steel, and has a stiff brass back, to keep it from bending. The brass back has a groove in it, and the saw is put in that groove, and then it is fastened to it. But the fly's saw is fixed in another way: there is a back to it too, but that back is not fastened to the saw. The groove is in the saw, and there is a ridge all along the back-piece, which just fits in the 
groove, and so the saw slides backwards and forwards, and the ridge always keeps it in its place. Besides all this, boys, the fly is better off than the cabinet-maker, for he uses only one saw at a time; but our little workman has two exactly alike, and they are so fixed that the creature first pushes out one, and when it is drawing that back, pushes out the other; so that it is all the time cutting, and does double work. I think the fly's saw is the best, too, for another reason. The saws of the carpenter and cabinet-maker have their teeth bent; first, one a little on one side, and then the next to it a little on the other side, and so on to the end of the saw; so that when sawing, the cut may be wide enough for the blade to move easily. Now the fly's saw has the teeth a little bent, or twisted, too; but it has something else: on the outside of every tooth there are a great many very small teeth, so that the outside of every one is just like a rasp, or file."

"But, Uncle Philip, it must take them a great while to saw a very little cut; they are so small."

"Yes, it does; but they persevere. It talkes them more than an hour and a half to make 
one groove, and sometimes they, will go on and make as many as six without stopping. That shows, boys, what perseverance will do." "And when it is done sawing, Uncle Philip, where does it keep its saws?"

"Oh, I told you they fitted in a case; but when the fly is done sawing, it uses the saws to put the egg in the place cut for it, and then it draws the saws almost entirely into the case, and drops upon the egg a sort of frothy stuff like a drop of soap-lather."

"What is that for?"

"I suppose it is to glue the egg fast, or else to keep the juices in the bush from hurting it."

"Well, this is a curious fly, Uncle Philip."

"It is strange, boys, because you never heard of it before; but it is a cunning fly, as well as a curious one."

"What does it do, Uncle Philip?"

"Why, when it is frightened, it will fold up its case and saws under its body, and draw up its legs, and pretend to be dead; and then it will not move, even if you stick a pin through it."

"Can you tell us any thing more about this fly?" 
"Nothing very strange, boys ; but we have found out two tools, I think, a saw and a rasp, and that is enough for one poor little fly to give us. Here, boys, are pictures of these saws; I have made them a great deal larger than they are in the fly, so that you can see them plainly."

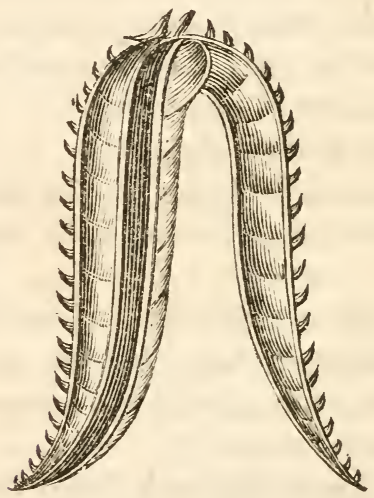

Saw of the Saw-fly, with Rasps shown in the Cross-lines.

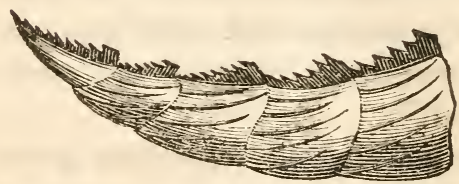

Portion of the Saw-fly's comb-toothed Rasp, and Saw. 
CONVERSATION II.

Uncle Philip tells the Children about Grasshoppers and Bees, that bore Holes with $a$ Gimlet.

"WfLL, Uncle Philip, here we are again, to hear more about the tools that animals work with ; we have seen in the bark of trees, and old wooden posts, little holes as round as a gimlet could make, and we have been thinking whether any of these little creatures have augers and gimlets, as well as saws. Do you know of any of them that can bore holes?"

"Oh yes, boys; I know of more than one that can bore as smooth and round a hole as any carpenter you ever saw. There are some of the grasshoppers that have an excellent gimlet. The contrivance has five pieces in it; two of the pieces make a case to keep the augers in, two more are the augers or borers, and the other is a piece between the two borers 
on which they slide; this piece has a ridge on each side of it, and the augers have a groove which exactly fits the ridge. Besides this, each auger ends in a knob, and that knob has teeth all around it." "Here is a picture of it."
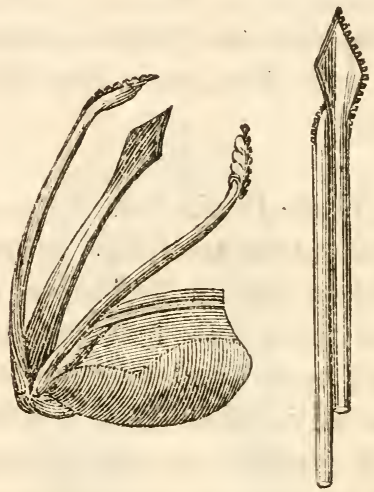

Ovipositors, with files, of the Grasshopper, magnified.

"But, Uncle Philip, what is the piece with the ridge for ?"

"Ah, boys, that piece shows the wisdom and the goodness of Grop. 'His tender mercies are over all his works:' he has placed that piece there to keep the borers stiff, so that they cannot get out of joint, or be broken, when the little workman is boring." 
"Well, this is very curious."

"Yes; but there are some of these insect workmen more curious still. Did you ever see a spy-glass? You know it is a round, hollow piece of wood, with brass tubes in it, which are made smaller and smaller, so as to slide into one another, when the glass is not used. Now there is a sort of gadfly (she is a little creature, too) which has exactly such a contrivance to keep her gimlet in. It is in four pieces, and the smallest piece ends in five sharp points, three of which are longer than the other two: she twists these five sharp points into one piece, and as some are longer and some shorter, when they are all put together, they make a sharp edge running all around, and are almost exactly like an auger or gimlet. When she wants to use it, she just shoots out the different tubes, so as to make a stem for the gimlet; and when she is done, she puts all back into its case again. "Here is a drawing of it, and I think that by looking at it you will understand what I have been telling you: I do not know whether men learned from this part of the fly how to make the case of a spy-glass; but I know they might have learned. 


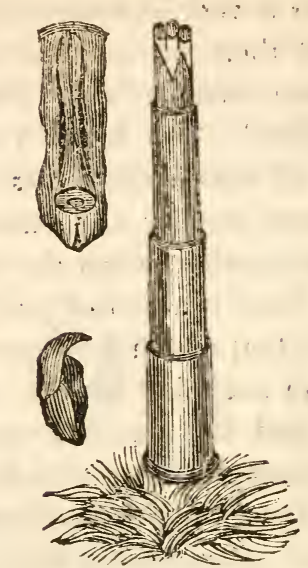

Oripositor or Gimlet of the Gadfly, greatly magnified, with a claw and part of the tube, distinct.

"There is also a bee, boys, which is called the carpenter-bee, because it is such an excellent wood-borer. It commonly looks for some old post, or dry plank, or withered part of a tree, to work in. It never works in wood that is green and has the"sap or juices in it; for the bee knows, just as well as any carpenter does, that it is very hard to get tools through such wood. I expect that you have seen sometimes, when an old post or dry board was split, a long hollow groove in the middle ofit; 
with little round thin:pieces of something like paper, about as thick as a wafer, fastened in it by their edges, one above the other, all the way through. These show the work of the carpenter-bee : she bored the hole, and she put those little partitions like paper in it, to separate the cells; and more than that, she made the partitions out of the dust she got by boring. She always likes, too, to get a piece of wood in a place where the sun can shine on it; and when: she: has made her choice, she begins to bore at first into the post in a slanting direction, and as soon as she has gone far enough in, she then turns and bores straight, with the grain of the: wood."

"Does she do it quickly, Uncle Philip ?"

"Not very quickly, for sometimes the wood is very hard; I have seen one of these holes nearly twelve inches long in a very hard oak board. Sometimes she has to. work at it for months; but she works steadily, boys, and that does a great deal. What makes it more tiresome is, that the poor little creature has to bring out all the dust she makes by boring."

"How large is the hole?".

"Oh, large enough to put my forefinger in, and sometimes fifteen "inches long. After she has bored it as deep as is necessary, she begins 
to divide it into separate cells. So she commences at the bottom, and puts in a quantity of what is called bee-bread, until it reaches about an inch in height ; on the top of this she lays an egg, and the bread is put there to feed the young one as soon as it comes out of the egg. She then makes a floor over it out of the dust, as I told you; she knows how to glue this dust together, and she brings it grain by grain from the heap in which she put it when she first brought it out: and she always begins by gluing the dust around the outside of the hole she has bored, and then glues another ring to that, and then another, and another, making each ring smaller and smaller, until she has it all filled; so that her floor, when it is done, appears like a parcel of rings of smaller and smaller sizes placed within each other. On the top of this floor she puts beebread, as before, and places another egg on it, and then covers it with a floor again; and so she goes on making cells and filling them with bread, and covering each with a floor, until she has filled up the hole."

"Uncle Philip, how do the young bees get out when the egg is hatched? It seems as if they were shut up for ever in prison."

"No, boys; there is a way for them to get 
out, and it shows the wonderful wisdom of God in teaching this poor bee how to contrive the matter. The egg which is put in the lowest cell being the oldest, the little worm that is afterward to be a bee will come out of that one first : now, you know, he never could get through all the cells over his head, filled as they are with bee-bread, so as to come out at the top of the hole. If he gets out at all, then, it must be at the bottom. The old bee knows this, and she so arranges these eggs that when the worm comes out it will be with his head pointed downwards; he falls to eating his bread, and so eats himself down to the bottom of his cell, and there he finds that his mother has bored a hole from his cell to the outside, and through that he comes out. When his brother in the cell above him has eaten his way down to the bottom of his cell, he just eats through the floor and gets into the cell below, which is then empty, you know, and walks out at the same hole which his older brother used before him. And so all the rest one after another eat their way downwards into the empty cells below them, and get out at the same back-door, which their mother made by what we call her instinct, 
which just means the share of wisdom which God gives to the lower animals to show them how to take care of themselves."
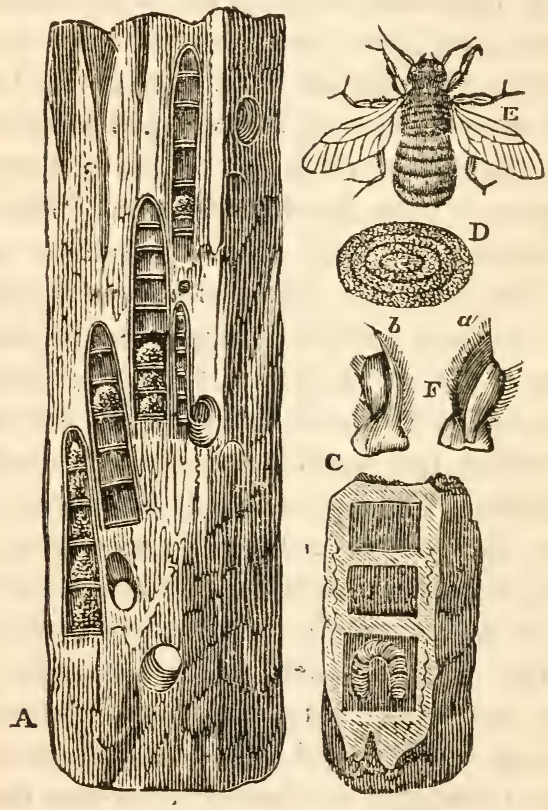

A, represents a part of a post, tunnelled in several places by the violet carpenter-bee; the stick is split, and shows the nests and passages by which they are approached. $C$, a piece of thin stick, pierced by the carpenter-bee, and split, to show the nests. D, perspective view of one of the partitions. E, carpenter-bee. F, teeth of the carpenter-bee, greatly magnlfied; $a$, the upper side; $b$, lower side. 
"Why, that instinct, as you call it, Uncle Philip, is a curious thing."

"Very curious, very curious indeed, boys ; and at some other time, if you wish, we will talk more about it, and I will tell you a great many stories of animals, which will show you their instinct. But for this time I have told you enough to keep you thinking until we meet again. So now just look at this picture of the carpenter-bee's house, and then you may go home."

\section{CONVERSATION III.}

Uncle Philip tells the Children about Animals that are Tailors.

"Uncle Philip, we are very glad to see. you, and we think we have found out something to ask you, about a kind of work which men do, that no other animal can accomplish. As we came along this morning to visit you, and were talking of what you had told us of insects that, like carpenters, could saw wood 
and bore holes in it, we passed by the tailor's shop, near the church; 'and now', said we, 'we have found out something which will puzzle good Uncle Philip: there are surely no tailors among the lower animals; so we will ask him to-day to talk about creatures that can cut out cloth and sew it up with a needle.'"

"Ah, my dear children, there are a great many things which would puzzle Uncle Philip. I do not know every thing; nor do I suppose that I can find every trade in the world among the dumb creatures which God has made. But you have made a bad choice of a puzzle this morning, my boys; for there are tailors among the inferior creatures, and some pretty nice ones, too; at any rate, they always cut so as to fit exactly."

"Why, Uncle Philip! You do not mean to say that they can cut out cloth, and then sew it up again with a needle and thread!"

"No, boys; I do not think it is to be expected that they should take a pair of shears and cut a piece of cloth, or put a piece of thread through the eye of a steel needle; any more than we expect the insect that saws, to go to the cabinet-maker, and borrow his tool 
to work with. But with the instruments which God has given to them, they will cut what is cloth to them, the leaves of trees and flowers, and will sew them together too: and, now I think of it, there is one that will cut his garments out of our cloth."

"Pray let us hear about them, Uncle Philip."

"Softly, boys, softly. I have two things to say to you before I begin. In the first place, I am very glad to hear that you think and talk among yourselves about the things which I tell you : and in the next place, I know that you love $m e$, and therefore would not wish, by puzzling me, as you call it, to produce mortification or vexation; nor do I think that I should have felt either vexed or mortified had I not been able to find tailors among the lower animals; but I do not wish you to take pleasure in puzzling people; for it is very apt to produce in you a feeling of triumph, and to make you vain: and you must remember that for one of your questions which cannot be answered, a thousand might be put to you, of the answer to which you would be ignorant. No man, my dear boys, knows every thing. Wise men talk with each other, that 
they may learn from each other; and the wisest are not ashamed to acknowledge their ignorance of some things; and I believe they take very little pleasure in puzzling. It is our duty to learn all that we can, and to be always willing at a proper time to teach others what we know."

"Thank you, dear Uncle Philip, for your advice. We did not mean to triumph over you, if you had not been able to tell us of tailors among the animals. But we see that you are right. We might get a foolish habit, which would do us harm."

"Exactly what I meant, boys; and now let us begin. And first we will talk of the cutting out, as the tailor always does that before he sews. There is a kind of bee* which, like some of the insects we have already spoken of, is furnished with a borer. With this she forms a round hole, like that made with an auger or gimlet; in a hard-trodden path, or sometimes in a piece of soft decayed wood. It is in making her nest in this hole that she plays the part of a tailor, for the nest is made of leaves, sometimes taken from the rose, at others from the birch, ash, or other

- Megachile centencularis. 
trees. The little creature cuts them commonly, and I believe always, into two shapes. They are either half-oval, that is, half the shape of the bowl of a spoon, or round, and are of different sizes. Sometimes she makes a mistake in the size, and when she finds it out, she alters it. These leaves are prepared to line the hole which she has bored, and she begins with the largest pieces; taking them into the hole, she winds around in it, until she has spread very smoothly a tube of leaves the whole length of it; she then closes up one end of it by rounding it off and doubling the pieces of leaf one over another. In this case she sets about making her cells. She takes three of her half-oval pieces which have been cut to fit, and contrives to roll them, so that the edge of one piece will just lap over the edge of the next ; these, when she has finished rolling them, make the hollow of the cell, which is not quite an inch high. She next turns up the ends of these pieces, which are cut to fit, so as to form the bottom: she then sets to work with three other pieces rolled in the same way inside of the cell just finished, turning up their ends as before to form the bottom; and within these she again 
works three others, so that her cell, when it is done, is of nine thicknesses of leaves. And you see why, though she cuts the pieces of the same shape, they are not all of one size : they are of three sizes, so as to make the cells withrn each other smaller and smaller."

"D.r, Uncle Philip, you have not said any thing about the round pieces which she cuts; how does she use them ?"

"I will tell you : after she has finished one cell she lays an egg in it, and fills it all round with food nearly liquid; now as the cell is lying down on its side, all this liquid food would run out if it were not corked up, and the bee therefore uses her circular pieces to stop up the celis."

"And does she really make these round pieces to fit the cell ?"

"Yes, boys, exactly; and they are cut too as regularly as if they had been first measured and marked with a pair of compasses. And, more than this, the little creature will fit one in in less than a minute. But the most curious thing is, that sometimes she will fly off to a distance to get this round piece, and bring back one which will exactly suit; so that it really seems as if she carried the size in her 
head. After finishing one cell she will make another, until she has completed as many as she wants; and then, as she always builds them one upon another, they appear like a parcel of thimbles stuck into each other and put into a case : and here is a picture of it."

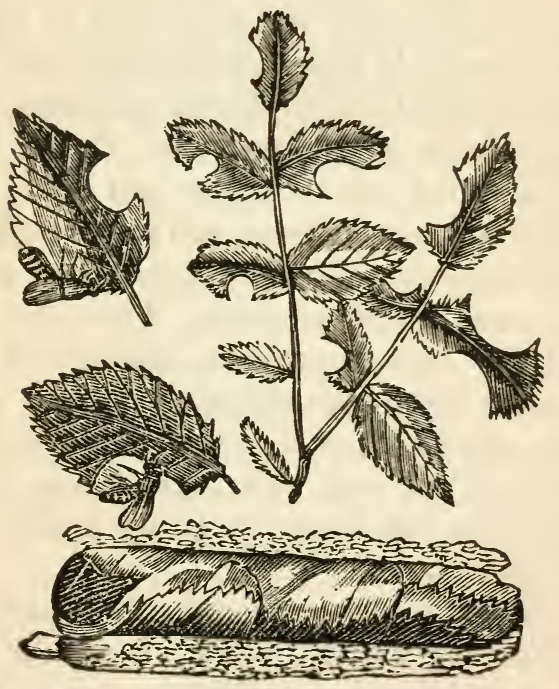

Rose-leaf-cutter Bees, and Nest lined with Rose-leaves

"This is very wonderful, Uncle Philip; and it does seem like cutting out pieces to fit." 
"Very true: but this is not the only cutterout of leaves among the bees. There is another kind, called the poppy-bee, ${ }^{*}$ because it uses the scarlet leaves of the poppy-flower to line its cell. It makes its hole in the ground, as smooth and regular and polished as can be, and then proceeds to line it all around with pieces of the leaves, and cuts them to fit as she goes on. If a piece is too large she will trim it down to the proper size and shape, and always carries away the scraps. Now if you should take a pair of scissors and try to cut the leaf of a poppy-flower, you would wrinkle it, but this little workman will spread out what she cuts as smooth as glass. When she has lined this hole throughout, and carried the lining out beyond the entrance, she fills it with honey and pollen, or bee-bread, as it is called, about half an inch high, lays an egg, then folds down the leaves on it, and finally fills the upper part with earth."

" "Then she was not working for herself?"

"No; she was providing a house for her young, and Gop has taught her thus to take care of it.

"I will now tell you of another little work-

* Osmia papaveris. 
man, which I have heard called the cloakmaker, because it makes for itself a mantle which really appears very much like a cloak; and, stranger still, this cloak is lined throughout with silk."

"Can it be possible, Uncle Philip?"

"Listen, and you shall hear. These mantle-looking cases are made by the larva, as it is called, or grub of a little moth which forms a covering of pure silk; this silk it spins from itself ; it is not woven so as to appear like our silk, but still it is real silk, and is worked into a great many thin scales, which lap over one another like the scales of a fish. But this is only the lining of the cloak. This little tailor is the field-moth, which first eats what it wants from a green leaf, and then, from the thin membranes left, sets about making its mantle : and it makes it of two pieces cut out and joined together with a seam, just as a tailor would make it."

"How does it go to work, Uncle Philip?"

"Why, I will give you the account as it was given by a gentleman* who was very fond of observing insects, and who watched one of these little creatures. He says that from the 
thin membrane of the leaf it first cut two pieces just equal in size and of exactly the same shape ; each of these pieces was to form one-half of the cloak, and this he says was done wonderfully fast. He noticed, too, that one end of each piece, that which was meant for the bottom of the cloak, was just twice as long as the other end, which was the top. The insect then placed itself between the two pieces while they were lying flat; it afterward brought the two sides where the seam was to be, together, and fastened them at certain places, still leaving, however, considerable spaces open. It then began to turn and twist its body about in all directions, until it moulded the pieces into a hollow form to fit. When it found that it would fit its body, it brought the edges of the seam close together through the whole length, and contrived to sew or fasten them so neatly together, that when the gentleman looked, even with a magnifying-glass, he said he could hardly find the seam. The whole was lined with the silk spun from itself, and was finished in about twelve hours."

"Why, this little workman is the strangest of all : but, Uncle Philip, you said there was 
one of these animal tailors that cut his garment out of cloth : pray tell us of him."

"When I said that, boys, I was thinking of the clothes-moth.* They make their coats of wool commonly taken from our cloth, and silk drawn from their own mouths; and the strangest thing concerning them is, that when they outgrow their clothes they will piece them to make them larger. Suppose the insect wants it longer, it adds a new ring of wool to the end : suppose it wants it wider, it slits the case or garment, not from one end to the other, for this would leave it naked, but it splits it half-way down the sides, and when it has filled it in with proper pieces, it splits the remaining half, and puts other pieces in them. There is another curious thing about this tailor: it always makes its coat of the same colour with the cloth from which it takes the wool; so that if it has first made its garment of a piece of blue cloth, and is placed on a bit of red cloth when it wishes to enlarge it, you will see its work exactly, for the pieces which it puts in will be red. This is the little fellow, boys, which does so much mischief to our clothes."

* Tinea sarcitella. 
"Well, Uncle Philip, one can almost forgive his mischief for the sake of his ingenuity. But you have said nothing yet about needles; how do these little creatures sew?"

"Why, they have what serves as a needle to them : but I can tell you of another animal which sews with a needle a great deal plainer to be seen than that of these little insects."

"Pray let us hear of him, Uncle Philip."

"I must go among the birds to find this workman. There is a kind of starling, called the orchard starling, ${ }^{*}$ about which, Mr. Wilson, a gentleman who has written a great deal concerning the birds of our country, gives a very curious account. He says that this bird commonly hangs its nest from the twigs of an apple-tree, and makes it in a very singular manner. The outside is made of a particular kind of long tough grass, that will bend without breaking, and this grass is knit or sewed through and through in a thousand directions, just as if done with a needle. The little creature does it with its feet and bill. Mr. Wilson says that he one day showed one of these nests to an old lady, and she was so much struck with the work that she asked

- Ieterus mutatus. 
him, half in earnest, if he did not think that these birds could be taught to darn stockings? Mr. Wilson took the pains too to draw out one of these grass threads, and found that it measured thirteen inches, and in that distance the bird who used it had passed it in and out thirty-four times."

"Why, this was sewing, sure enough."

"Yes; and I saw, when I was in the West Indies, another kind of starling* which will cut leaves into a shape like the quarter of an orange-rind, and sew the whole very neatly to the under side of a banana-leaf, so as to make one side of the nest. But, boys, there is another most beautiful little bird, which is called the tailor-bird, because it sews so well. $\dagger$ It first picks out a plant with large leaves, then it gathers cotton from the shrub, and with the help of its fine long bill and slender little feet it spins this cotton into a thread, and then using its bill for a needle, it will sew these large leaves together to hide its nest, and sew them very neatly, too."

"Why, dear Uncle Philip, this is the most wonderful tailor of them all."

"He is, indeed: but, my children, what do

- Icterus bonana.

$\dagger$ Sylvia sutoria. 
we learn from all that I have been telling you? Who made these little creatures with such curious skill, and taught them to work so well? It was the same God who made us; for such wonderful things never came from what people call chance. Chance, boys, never made any thing : and how very wise he must be to form such nice little workmen; and how very good thus to teach them how to take care of themselves. The Bible says, truly, that ' his tender mercies are over all his works.' And I think, boys, we may learn another thing : it is, not to be so very proud of what we know ; for I rather suppose that we shall often find that the lower creatures around us understood many of our trades long before we found them out."

"Yes, Uncle Philip, it is likely that these little fellows you have been telling us of this morning were the first tailors in the world."

"Very likely, very likely indeed, boys. But now I must bid you good morning; for here comes our good clergyman, and I am going with him to see a poor sick woman."

"Good morning, Uncle Philip; we will come again on Saturday." 


\section{CONVERSATION IV.}

Uncle Philip tells the Children about the first Paper in the World, made by Wasps.

"Aн, boys! how do you do? This is Saturday, and I have been expecting to see you come for some time."

"Why, Uncle Philip, we should have been here sooner, but we went round by the old mill; because we thought that perhaps we might find in some of the old timbers, holes bored by some of those industrious little carpenters you told us about."

"Well ; and did you find any?"

"No; but we found something else, whick we have brought to show you : and we have been talking about it all the way. We have not discovered any new tools among the animals, but we think we have found out a trade that some of them work at; and we wish you to tell us if we are right."

"Oh, that I will do, with pleasure, if I can. D 2 
What is the trade that you think you have discovered?"

"It is paper-making, Uncle Philip. We have found this part of a wasp's nest, which we have brought along; and as you told us it was always best to notice every thing closely, we examined this, and it appeared so much like coarse paper that we thought (for we knew it was made by wasps) that man did not make the first paper in the world."

"Well, boys, that was not a bad thought. Now you see the advantage of taking notice of things, and of thinking about what you see. You are perfectly right in supposing that wasps make paper; and, if you please, we will talk this morning about the wasps."

"Oh yes, yes, by all means, Uncle Philip; and we will thank you, too."

"I must first tell you, then, that of the wasps there are several kirds. Some build their nests under ground, and some hang theirs in the air to the limb of a tree. This part of a nest which you have found belonged to the last kind; but I will tell you something about both. But before I begin let me get some drawings I have, which will help us to understand better. I have them. And 
now, of the wasps which build under ground. As soon as the warm season begins, the first care of the mother-wasp is to look for a fit place in which to build; and in the spring of the year she may very often be seen flying about a hole in the bank of a ditch, and looking into it. These holes which she examines are the old houses of field-mice or moles, and some persons have thought, what I expect is true, that she likes to take such old holes, because they save her a great deal of hard work. But still, as the holes are not large enough for her use, she has a great deal of labour to make them do. So she goes at once to work, digging in the hole she has chosen, and makes a winding, zigzag gallery, about two feet long, and about an inch in width. She digs out the earth, and carries it out, or pushes it out behind her as she goes on. This gallery ends in a large chamber or hole from one to two feet across when it is done : and now she is ready to begin her nest."

"Now then, Uncle Philip, she will begin to make paper, will she not?"

"Yes; but here I ought to tell you that it was a long time before men found out what she made it of. Do you remember mv tell- 
ing you of a gentleman who watched the little cloak-maker to see how he made his garment? Well, this gentleman, whose name was Reaumur, was trying for twenty years, he says, to find out how the wasp made paper, before he succeeded. At last, one day, he saw a female wasp alight on the sash of his window and begin to gnaw the wood; he watched her, and saw that she pulled off from the wood fibre after fibre, about the tenth part of an inch long, and not so large as a hair. She gathered these up into a knot with her feet, and then flew to another part of the sash, and went to work, stripping off more fibres or threads, and putting them to the bundle she had already. At last he caught her, to examine the bundle, and found that its colour was exactly like that of a wasp's nest; but the little ball was dry; she had not yet wetted it to make a pulp of it which could be spread out. He noticed another thing, that this bundle was not at all like wood gnawed by other insects; it was not sawdust, but threads of some little length bruised into lint. He then set to work himself with his penknife, and very soon scraped and bruised some of the wood of the same window-sash, 
so as to make a litle ball exactly like the wasp's. MIr. Reaumur thought that this was the stuff out of which the wasp made paper, and it has since been found out that he was right. The animal wets its little bundle of bruised wooden fibres or threads with a kind of glue that it has, and this makes it stick together like pulp or paste; and while it is soft, the wasp walks backwards, and spreads it out with her feet and her tongue, until she has made it almost as thin as the thinnest paper. With this she lines the top of the hole in which she is going to build her nest, for she always begins at the top. But this is so thin that it would be too weak to keep the dirt from falling in; and therefore she goes on spreading her papers one upon the other until she has made the wall nearly two inches thick. These pieces are not laid exactly flat on each other like two pieces of pasteboard, but with little open spaces between, being joined at the edges only. This is the ceiling; and when it is finished she begins to build what may be called the highest floor of the nest; this she makes of the same paper in a great number of little cells all joined together at the sides; and instead of fastening this 
floor to the sides of the nest, she hangs it to the ceiling by rods made also out of this paper: these rods are small in the middle, and grow larger towards the ends, so as to be stronger. Here is a drawing of one.

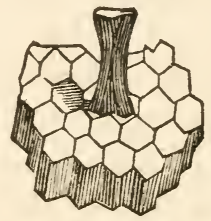

The Cut represents one of the Rods from which the Floors are suspended.

She then makes a second floor, and hangs it under the first by rods as before; and the whole of it, when finished, if it should be cut straight through the middle, would appear something like the following picture of one which I made some years ago." 


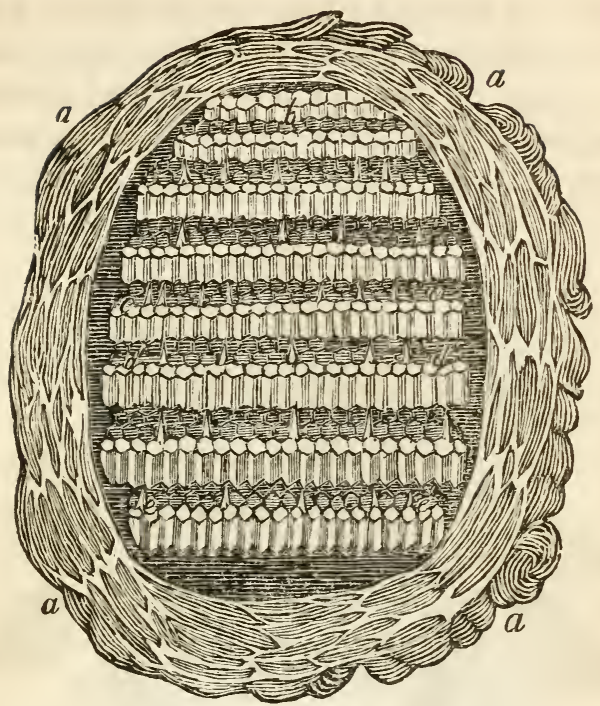

Section of the Social-Wasp's Nest.-aa, the outer wall; $b, c c$, five small terraces of cells for the neuter wasps; $d d, e e$, three rows of large cells for the males and females.

"This is a very ingenious little papermaker, Uncle Philip."

"Yes, boys, it is so. This of which I have been telling you is the ground-wasp. The tree-wasp makes its nest of paper prepared in the same way; and the nests are of different shapes. One makes it in a round 
flattened ball, not much larger than a rose, and when cut open it shows layer upon layer of leaves of the same thin grayish-looking paper. This kind is not so common, however. Here is one of their nests.

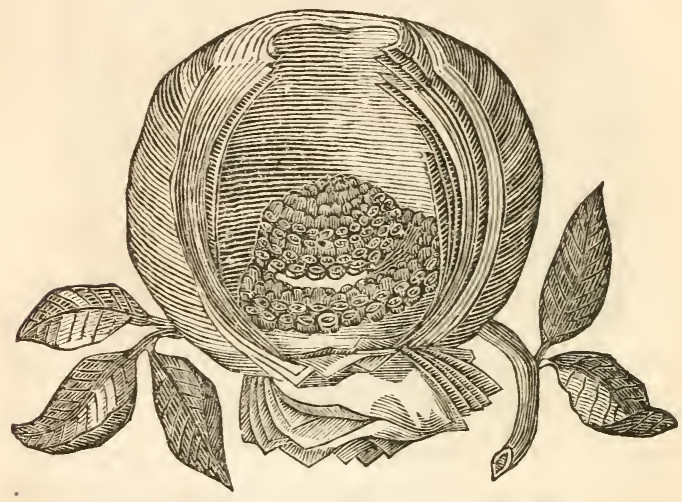

Wasp's Nest.

"Another makes its nest of cells placed in separate floors, but without any outer wall to keep off the rain ; and the most curious thing in this nest is, that it is not placed in a horizontal way; that is, it is not placed with the floors level, because then the cells would catch the rain, and the nest would be spoiled; but it is always placed slanting, so that the rain 
may run off. It is always placed, too, so as to face the north or the west, and I suppose it is because the wasp knows that it is in more danger of rain from the south and the east. Here is a nest of this kind."

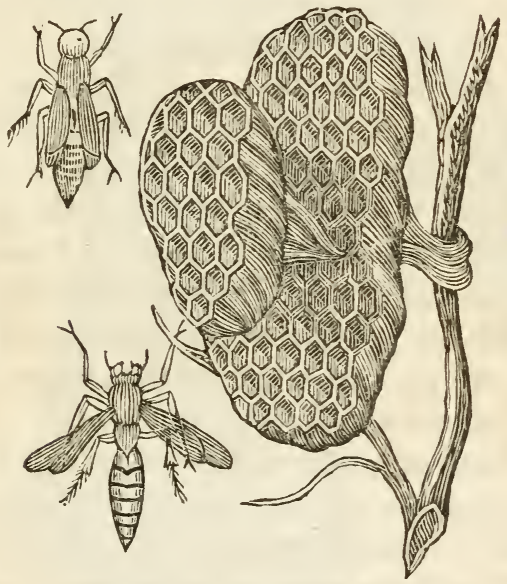

Wasp's Cells attached to a branch.

"Ah, Uncle Philip! this must be a kind of lazy wasp. It does not choose to take the trouble to cover up the house, and so it hangss it slanting, to make the rain run off."

"It may be so, boys; but I think that in making this wasp lazy, you make it a very sensible wasp; else how should it know that 
water would run down a slanting surface? But I cannot believe that it is so lazy; for, though it does not cover up the whole house in a paper shell, yet it does what no other wasp does, it covers its nest with a complete coat of shining, water-proof varnish, to prevert the rain from soaking into the cells. And putting on this varnish, I can tell you, is no trifling work. It forms a pretty large part of the labour of the whole swarm belonging to the nest; and sometimes you may see some of them at work for hours at a time, spreading it on with their tongues. No, my lads, he who wants an example of laziness, will not find it among the wasps.

"But let us come back to the paper. Hornets make paper for their nests much in the same manner as the rivasps do, only it is coarser. There is, however, one kind of wasp which makes a sort of paper more curious than this which you have found. It is not a wasp found in this country at all. It is the Cayenne wasp, and so smooth, strong, and white is the outside of his nest that it appears like a card, and he is for that reason sometimes called the card-maker wasp. He hangs his nest on the branch of a tree, and it is so 
hard and polished on the outside that the rain rolls off from it, as if it were glass. A little hole in the lower end is left for the animal to pass in and out; and in this picture of it, which $I$

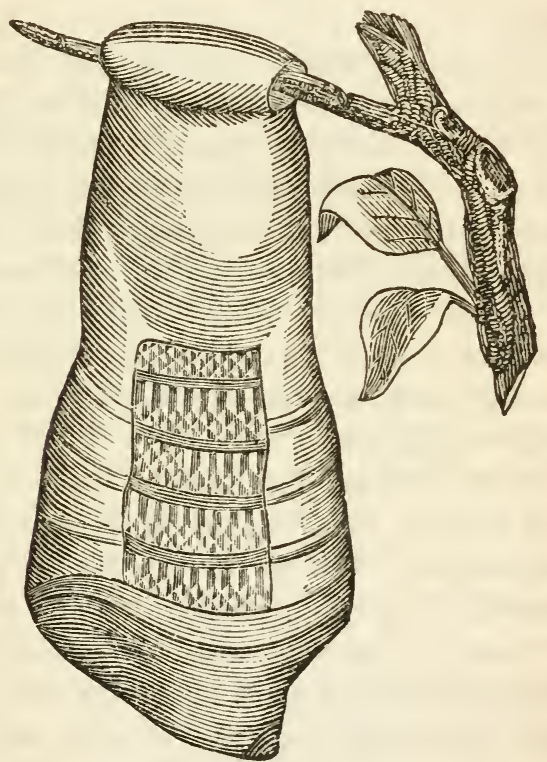

Nest of the Card-maker Wasp, with part removed to show the arrangement of the Cells.

have, a piece is left out of the side to show how the cells within are fixed."

"Well, then, Uncle Philip, we were right in thinking that wasps were the first paper- 
makers; and very glad we are that we saw this old piece of a wasp's nest. Who would have thought that so much could be learned by picking up this old scrap of a wasp's work!"

"Very good sense, boys, in that thought. A wise man will learn something from almost any thing. Use your eyes, and think of what you see. Now in this very trade of papermaking, I think that man would have found it out a great deal sooner if he had watched the wasps at their work. They have been excellent workmen at this business from the beginning; and man has gone on learning little by little of this very trade, as I will tell you at some other time, when he might have made a long step at once, had he but noticed wasps and hornets. We go on very slowly sometimes in learning to make a trade as perfect as it can be: the poor animal, with its knowledge such as God gave it, is often our superior. These dumb creatures cannot teach us every thing; there is a point to which they can go, and no further: but as far as they do know, their knowledge is perfect; and I make no doubt that a great many useful things not now known will hereafter be found out by watching dumb animals." 


\section{CONVERSATION V.}

Uncle Philip tells the Children a Story about Tom Smith; and of Bees with Brushes and Baskets, and of a Bird with a Chisel, and a Gnat with a Lancet.

"Uncle Philip, as the day is fine, instead of sitting here, will you walk with us, this morning?"

"Yes, boys ; let me get my cane and hat, and we will take a ramble; perhaps we may see something, if we will use our eyes. Where do you wish to go?"

"Oh, we do not care much, if you are with us, which way we walk; any course will be pleasant."

"Come on, then; we will cross the river, and go down on the other side beyond the old mill, where you found the wasp's paper. And now, such of you as will, may keep a look-out for curious things, while the rest of us will talk together.-Boys, do any of you know Tom Smith ?" 
"Know him! Why, Uncle Philip, everybody in this part of the country knows him; he is such a shocking drunkard, and swears so horribly, that nobody can forget him; and what makes it worse, he is an old man, too. His hair is almost as white as yours, Uncle Philip."

"Yes; he is just about my age. We were both born here, and I have known him ever since we were boys; and when we played together as children, over this very field which we are now crossing, or caught fish in the river down yonder by the rocks, there was not a more decent, well-behaved, handsome boy among us than was Tom Smith. Poor Tom lost his father when he was about twelve years old, and his mother, having no other child, indulged him, until he was sent to the city to go into a store. But Tom then, boys, had good principles; he neither swore nor got drunk. In a little time he fell into bad com= pany, and they led him astray by degrees, He was so good-natured (as they call it), boys, that he had never the firmmess to say no to the proposals of his companions. He went with them to places of amusement; and instead of spending his evenings in his own 
room, reading, he was at the theatre, or dancing in some place, or at a supper with his young companions; and finally he began to play cards and billiards with them; while the inside of the church was a place which he never saw. He was cheated by his companions; and too honest he was then not to pay what he lost by gaming: he wrote to his poor mother, and told her the truth, as to his losses, and she sent him money to pay his debts, and told him to come home. He did come home ; and even after all that had happened, poor T'om might have been respectable and happy; for his friends were all willing to forget the past, and encourage him for the future. For a time he went on pretty well, and married an affectionate and good young woman, and his prospects were bright enough: but one thing, boys-one single thing, ruined his comfort for ever. In the city he had learned to drink: strong liquors.

"I remember, too, soon after he came home and married, that a man was hung not far from here for murdering his wife. The man was a drunkard, though he was quite sober when he killed the poor woman; and drunkenness had hardened his heart, I have no doubt, as it will the heart of 
any man. Tom was talking to me about that man, and I remember he said then that when a man began to drink, he could never say where it would end, nor what he would do: 'therefore,' said 'Tom, 'beware of the first drink.' But Tom, though he talked like a Christian and a man about it, did not act like one : for it was not long before he began to follow his bad habit, and he soon killed his poor mother; for she died of grief and sorrow, I think. His excellent wife speedily followed her to the grave; and Tom Smith left the village, a perfect vagabond, whom no one cared for. Where he went, or what he did for a long time, no person here knows. I went to other countries, and neither heard of nor saw Tom Smith until my return home, when I found him wandering about here, a gray-headed swearer and drunkard. He did not know me, and I never should have known him, had not some one told me who he was. And last night I received a letter from one of my nephews in the city, which informed me that Tom Smith had been tried in the court, and found guilty of stealing, and was sent to the state prison for ten years to hard work. There I suppose he will die for he is now old; and it 
is awful to think of what is then to become of his soul. Ah, my dear boys ! I could not help thinking, when I read my letter, of what that man said to me years ago-and I have told you his story, hoping that you will remember his words, 'Beware of the first drink.' The man who does that will never be a drunkard. And when old Uncle Philip is laid in the grave, boys, which must be before many years, remember, as you look upon the place, that he told you the story of Tom Smith, and charged you to ' beware of the first drink.'

"But here come some of the boys, running towards us; I suppose they have found something."

"Oh, Uncle Philip! Uncle Philip! Do come with the boys this way. Under that fence yonder there are a great many beautiful wild flowers, and a number of bees are as busy as they can be about them; pray come and see them."

"Well, I will; but not so fast, boys; you forget that I am an old man, and cannot run as you do.--So, here are, indeed, a great many industrious little workmen."

"What are they doing, Uncle Philip ?" 
"These are vorkers among the bees, and they are gathering the dust out of the flowers, to work it up into what is commonly called bee-bread. More tools here, boys !"

"Tools, Uncle Philip! Ah, we like that: pray let us hear of them ; what are they ?"

"Why, there is a brush and a basket in the legs of these little fellows; but they are so small that you cannot see them without a microscope."

"What is a microscope?"

"It is an instrument, made by fixing glasses in such a way to look through, that small things will seem to be very large. Do you not see how some of these little fellows are rolling themselves over in the inside of the flowers, so that the yellow dust is sticking to them? Now their breasts, and legs, and many other parts of their bodies are covered with very short hairs, which catch the dust. The last joint but one of each leg is made exactly like a brush, the hairs being longer there than on any other part; and with these they brush off the dust, and get it into two little heaps. The bags into which they put it, or rather the baskets, are in the thighs of the last pair of legs. These are hollow, so as to 
form a three-sided basket. The bottom of it is smooth and shining, and appears like horn, and all around the edges are placed very strong, thick-set hairs, like bristles."

"What are these for?"

"To keep things from falling out of the basket; and these bristles are so strong that even if they heap up more than the basket will hold, the bristles will keep it from falling. Here is a drawing of these legs.
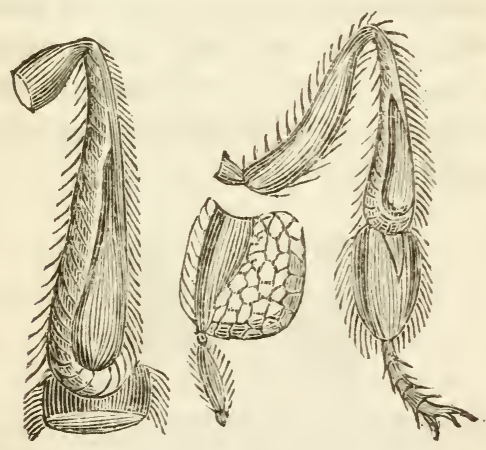

Structure of the legs of the Bee for carrying propolis and pollen, magnified.

Besides carrying this dust, they also carry what is called propolis."

"What is propolis, Uncle Philip?"

"It is a gum which is found upon some 
trees. This they work up into little balls, and knead it until it is a little dry, so as not to stick. This takes the bee sometimes as much as half an hour. When the balls are ready, she passes them backwards with her feet to the basket, puts them in, and gives them a pat or two to make them lie close; and when she adds more, she pats it still harder, and when the basket is full, away she goes to the hive. But there is another curious instrument about the bee. I mean its sting: this is like the head of a barbed or bearded arrow. There is a sheath for it when the bee does not wish to use it; and here is a picture of it.
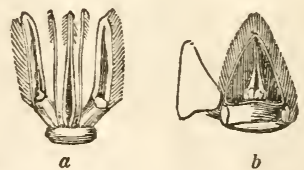

$a$, The sting of a Bee, magnified to show the barbed darts; $b$, the last ring of the abdomen of a Bee opened, showing the sting in its sheath.

But let us now continue our walk."

"Well, Uncle Philip, it is really very pleasant to walk with you : it seems as if you met nothing which could not teach us things worth knowing." 
"Why, my dear boys, there are, as I told you once before, a great many things which I do not know; and what I do know I am very willing to tell you. But you may learn just as I did,-by reading, by taking notice of things around you, and by thinking for yourselves. And I do not know any thing more pleasant to notice than the works of God. I see his wisdom and his goodness in every thing which he has made. I see them in the insects, and the birds, and the larger animals; I see them in the grass, and the flowers, and the trees; and I see them in the rocks and the stones upon the ground. All these things are well worth our attention, boys; the study of all these things around us is called the study of 'Natural History ;' and I think it is apt to make him who loves it a better man; at any rate, I believe that there have been very few who have been fond of it, who have not been amiable and benevolent men. But, hark! Do you hear that noise?"

"Yes, Uncle Philip; it is the sound of men chopping wood in that clump of trees."

"No, boys; it is like the sound of a woodcutter; and it is a wood-cutter, but he does not use one of our hatchets." 
"What is it that he uses, then ?"

"He uses the tool which God gave him. It is a bird, boys, which you hear: it is the woodpecker. See, there it is on yonder tree, and look, at the foot of it, there is something like a bushel of the bird's chips or dust. Its bill is a complete chisel; it is straight, hard, and sharp, with edges too upon the sides. It is not a very broad chisel, but still it is one, and used as we use ours. But the chisel is not the only instrument of that workman. Its tongue is worth examining. It bores a hole into a tree that is dead or decaying, to look for insects whose nests are in the tree; and when it reaches the cell where the young insect is, it uses its tongue to get it out, and it suits exactly for the business. In the first place, it is so long that the bird can shoot it out three or four inches longer than the bill is; in the next place the end of it is tipped with a stiff, sharp, long thorn; and in the last place, that thorn has little teeth on both sides of it, like that which you see on the point of a fish-hook these teeth are to keep the insect from falling off when it puts its tongue in the hole and sticks its sharp point into it to draw it out for food. So 
that besides the chisel, the woodpecker has a spear, or lance, or arrow, barbed (as it is called) or bearded at the point.

"But we are some distance, boys, beyond the old mill : suppose we now turn back towards home; I find the gnats rather troublesome."

"So do we, Uncle Philip; they have been jiting us for some time: it would be well if there were no such tormenting things in the world."

"I am not sure of that, boys. We may not always be able to find out the exact use of some of these little animals; but that only shows that we are ignorant, not that they are of no use. God would never have made them if he had not some wise purpose in doing so: I do not believe he ever wastes his power in making useless things. But what will you say about gnats, when I tell you that they have a tool to work with, and a very perfect one, too?"

"Why, we will almost forgive them for piting us."

"Biting you! They have not been biting with teeth : they are doctors, boys; they have only been bleeding you, and cupping you." 
"And what have they been bleeding us with ?"

"Why, with a lancet, to be sure; what should a doctor use but a lancet to let blood?"

"And has the gnat really a lancet?"

"Yes, it has: this instrument forms a part of what you may call the tongue of the gnat: it is made up of five pieces, which are shut up in a case, split from one end to the other; these give steadiness to the lancet when it is used. But the reason of the pain is not so much the wound of the lancet, as it is the fluid or poisonous juice which the gnat puts into the wound to make the blood thin enough for the insect to suck it up through a tube or case, which makes part of its mouth. Here is a drawing of part of a gnat's mouth.

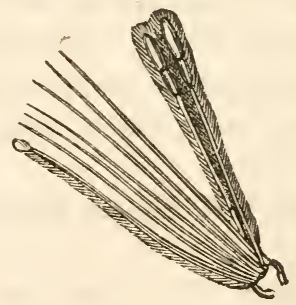


And here is a picture of the lancet or knife of a horse-fly.

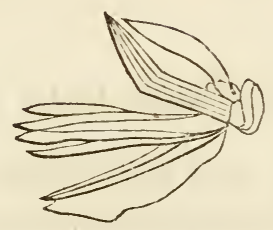

"We have now reached the bridge,--and here we must part; your homes are in one direction, and mine is in the opposite. I hope, however, that you have learned something in our morning's walk."

"We have, Uncle Philip, and we thank you much, and bid you, good day."

"Good day, boys." 


\section{CONVERSATION VI.}

Uncle Philip tells the Children about Animals that can do Mason's Work.

"Uncle Philip, we saw a very strange thing just now ; as we were coming, we saw a great many bees flying by us, and each one was carrying a little stone."

"That was strange, indeed. Did you find out any thing about them?"

"We asked a man who was near what they did it for, and he said that they carried the stones to prevent the wind, which is blowing pretty fresh, from tossing them about too much."

"That is a very silly story, boys, though it is a very old one : for I have seen them carrying what you call stones when it was quite calm, and there was no wind to blow them away. The man was very ignorant, or he would have told you another story, which would have been both strange and true." 
"Will you have the goodness, Uncle Philip, to tell us what it meant?"

"Very willingly, boys. What you saw I presume were bees. You remember that I told you there were several kinds of bees; and this one is called the mason-bee. This kind builds his nest of mortar, and was therefore called the mason-bee by Mr. Reaumur first, I believe."

"Where does it get the mortar, Uncle Philip ?"

"It makes it, boys. This kind of bee may be seen flying about, picking up sand, grain by grain, putting it into a heap, gluing them together with a sort of gum out of her own mouth, and building with them a foundation for her house. This little workman commonly builds against the side of a wall between two bricks where the mortar has fallen out; and if you should see one of the nests, it appears exactly like a lump of dry mud which has been thrown wet upon the wall out of a cartrut: but when you examine it closely, you may see a great many small stones in it, more than is common in mud: a hundred people, though, might pass by it, and never think it was any thing more than a lump of dirt, which 
68

had been thrown upon the wall when it was wet, and had afterward dried there. Here is a picture of one of these nests.

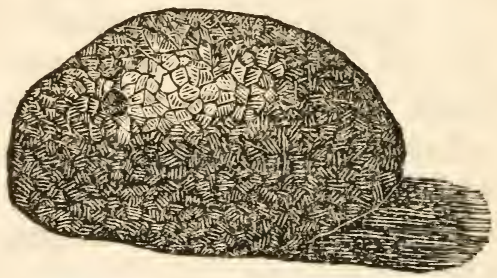

Exterior wall of Mason-bee's Nest.

You see there is a small hole in it; this leads to a cell inside about an inch deep, and shaped exactly like a lady's thimble; the inside of this cell is polished smooth, and appears like a wall of plaster, except that it has little yellow stains upon it. Here is the bee that makes it.

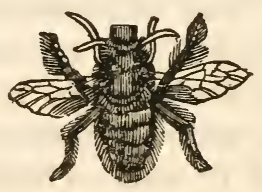

Mason-bee.-Natural size.

In making this mortar to build with, the bee 
will sometimes add earth that is soft to its grains of sand, and when the lump is about the size of a small shot, it takes it up and flies away with it, to work it into the wall."

"Does it always use sand, Uncle Philip?"

"Not always : sometimés it takes wet clay, and will dig into a bank of clay baked hard by the sun on the outside, so as to get that which is wet.

"Mr. Rennie, a gentleman in England who is very fond of watching insects, and has found out a great many curious things about them, has given an account of some of these bees which he noticed at work. Every one was carrying out of a hole in the clay-bank a small lump of clay; and on catching one of them, he found that this lump was wetter than the clay in the hole, so that the bee had moistened it, and worked it together, to make it stick like good mortar. These lumps too were larger than a shot; they were as large as a gardenpea."

"How long did it take them to work up the lump?"

"About half a minute, Mr. Rennie says. He watched one of these little creatures, and found that she was building on the inside 
wall of a coal-house, where the bricks and mortar were left rough : she was at work between two of the bricks where the mortar had fallen out, or where the bee had taken it out. And the conduct of the bee at her house was very different from what it was at the clay-bank. She was not frightened, but went on working when any one came near the clay-bank; but at her house she seemed afraid that it should be found out where it was. She would alight first on the roof outside, as if she merely wished to rest herself; and when she flew into the coal-house she would not go directly to her nest, but would settle on a shelf, and sometimes pretend to be examining a great many places in the wall between different bricks; and at last, when she supposed there was no risk, or when there was nothing to alarm her, she would fly to her nest, and go to work with all her might in fixing her piece of clay to the wall."

"Why did she wish her house not to be found out, Uncle Philip?"

"Mr. Rennie supposed it was her instinct: she had seen probably some of the insects which would destroy her young, watching her to see where she was building; and sometimes 
after flying nearly to her nest with a load, she would turn back and fly towards the claybank, or take a large sweep off in another direction, and so come to her house.

"Besides the mason-bee, boys, there is the mason-wasp, which I have heard some persons call the dirt-dauber: it is very common, especially in the southern part of the United States. It works very much like the masonbee, orly it is apt to fix its nest under the eaves of old houses, which I think the masonbee never does.

"There is also another kind of mason-wasp which will actually break a hard brick. Mr. Rennie says that he saw one at work on a brick of a hard yellow kind. Whether the wasp found a hole in the brick to begin with, he did not know; but if he did he was hard at work making it larger: he would break off a piece as large as a mustard-seed at a time. Here is a drawing of that kind of wasp; and the insect is no larger than the picture.

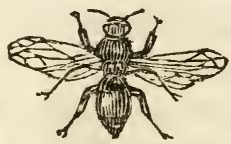

Mason-wasp.-Natural size 
It seems wonderful that so small an insect should have so much strength. Here is a picture of its jaws, seen through a microscope, so as to appear a great deal larger than they really are.

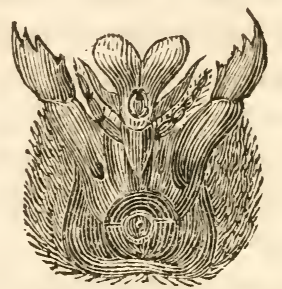

Jaws of Mason-wasp.-Greatly magnified.

"I do not know, boys, that the masons we have been talking of, show us any tools like those with which men who are masons work; but they show us, at any rate, how to make mortar by kneading or working it together; and they certainly show us that we were not the first who built walls. But there is another kind of mason who works in stone. He picks out the stones which are of proper size, and he fastens them together with mortar really as men do."

"Pray tell us of him, Uncle Philip."

"I will. The insect I mean is the caddis- 
worm, which is to be found sometimes in ponds, and very often in springs of fresh water. There are several sorts of them, but the one I am thinking of now, builds a stone house to live in. These worms are in the habit of making a little tube, sometimes of sand, or shell, or wood, or leaves, or stones, to live in; and their skill consists in joining these perfectly, and making them stick together. But we are talking now of the caddisworm that uses stone. What the worm has to do is to make a tube out of small stones, that shall have a hollow about as large as a wheat straw, and be perfectly smooth inside. This is a pretty hard task-at least it would be very hard to us. When the stone-mason wishes a stone of a particular size or shape, and camnot find it, he takes his hammer and breaks one until it will suit; but the caddisworm has no hammer, and must take the stones just as it finds them. The little insect then has to pick out a great many stones before he gets the right one, because they have so many little rough points about them that it is very difficult to get those which will make the tube perfectly smooth inside. Romember, too, that the bottom or lower side of 
this stone case has to be pretty nearly smooth, so that the worm can drag it along on the bottom of the spring or pond (for it never comes out of it), and you will see that the picking out of the stones alone is no trifle. But besides this, it has to fasten them together with mortar."

"And can the worm really do this, Uncle Philip? Will not the water wash the mortar all away ?"

"It certainly would if it were like common mortar. It was a long time that men lived before they found out a mortar that would remain, and grow hard under water. When they want to build a wall that is to be under the water, they use a cement which is called pozzolana; it is made of lava out of a rolcano, and is water-proof. Our caddis-worm has a cement too, which is better than pozzolana, and though it has been tried, it cannot be melted or dissolved in water. Here is a drawing of the stone nest of a caddis-worm."

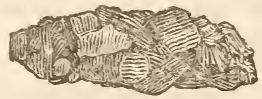

Stone Nest of Caddis-worm.

"Uncle Philip, you said that sometimes these worms built their nests of other things 
besides stones; let us hear something of them, if you please."

"Very willingly, boys. Some build of shells : here are pictures of their nests.

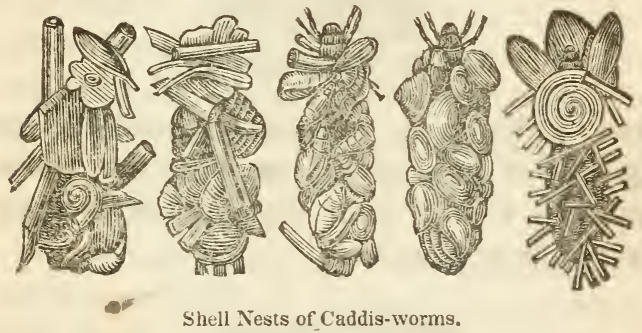

Some build of leaves, and others of pieces of reed or light bark.

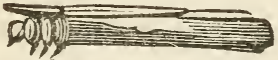

Reed Nest of Caddis-worm.

And a curious thing about those which build of light pieces of bark or reed is this, that they will make the top-piece come over so as to hide their heads, and prevent you from seeing them. Some build of sand; and then as the house would be so light that the water run- 
ning from the spring might wash it down and carry it away, the wonderful little creature takes care to anchor it by fastening a pretty large stone to it when it has nearly finished it.

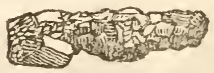

Sand Nest, balanced with a Stone.

And as the worm anchors it when it is too light, so it lightens it when it is too heavy, by fixing a bit of light wood or hollow straw to it to buoy it up."

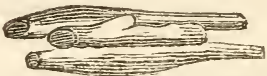

Nest of Caddis-worm, balanced with Straws.

"Well, this is truly a wonderful insect, Uncle Philip."

"Truly so indeed, boys. In all these cases it uses its water-proof cement, and if you break its house to pieces, and will patiently watch, you may see it build another. The insect always lives with its head out of doors, and its body inside; so that its head is firm and hard, while its body is soft."

"Uncle Philip," said one of the larger boys, "there is one thing I have been thinking 
about, as you have been talking: these little masons have no trowel, but I believe I know of one animal that uses something like that tool."

"Ah! What animal is it?"

"Why, I was reading the other day something about the beavers building their dams and their houses, and the book said that they built their houses of logs first, and then plastered them with mud, and that they used their tails for trowels."

"I am very glad to find that you remember what you read; but I am sorry that your book did not tell you the truth. There have been very strange stories told about the beaver; and these stories have been taken from one book and printed in another, so that an untrue account has gone down for a great many years. The beaver is very ingenious, but is not quite so much of a mason as you suppose."

"Well, Uncle Philip, will you tell us the truth about it?"

"Yes, boys, I'will, so far as I know it myself. I have seen these animals, for they were once a great deal more common in our country than they are now : and many of the stories told a 2 
of them are not true. But before $I$ begin, let me tell you of one book which I think does tell the plain truth about them; and the truth is curious enough."

"What book is it, Uncle Philip?"

"It is a book written on American Natural History, by Doctor John Godman. I knew him, boys, and a most excellent man he was. $\mathrm{He}$ is now dead-and he died a Christian. The book he wrote you will find worth reading, when you get old enough to understand it. But now for the beaver.

"His tail is very broad and flat at the end, and might be used very well for a trowel; but when he builds his house he does not cut down trees, and place them first, and then fill up the cracks with mud-mortar; but all the sticks and mud (and stones too when the beaver can get them), are first mixed up together, and the beaver builds his house with this from the very foundation. As soon as he has placed a lump of this stuff upon the wall, he turns round and gives it a blow with his flat tail; and that, boys, is all he does with his tail for a trowel. Sometimes he slaps his tail upon the water when he is swimming; and some persons have supposed that this was done by 
the king, or ruler, to call his workmen. It may be so, but I do not believe it, because they almost always dive as soon as they have slapped the water; and I think it is probably a part of their motion in diving. In the autumn they cover the outside of their houses with mud, and they walk over it as they are at work, and their tails drag along upon it ; and this I expect made persons first suppose that they were plastering it, with the tail for a trowel. When they are caught and kept, boys, they still keep up this fashion of slapping with the tail; so that I rather think it is part of the nature of the animal.

"At another time, perhaps, I will tell you more about the beaver; but it is now late, and I must bid you good morning."

"Good day, Uncle Philip." 


\section{CONVERSA'LION VII.}

Uncle Plitip talks to the Clitdren about Animals that throw Dirt with a Spade; and about an Animal with a Hook; and about one that is a Wire-drauer.

"Boys, I have some men at work digging a small ditch for me, and I wish to see them; will you go with me ?"

"Oh, yes-very gladly, Uncle Philip; for you will be sure to tell us of something curious before we come home."

"Come on, then: yonder are the men at work; they have been very industrious, I see."

"But, Uncle Philip, look! 'There is one of the men putting a bottle to his mouth. Is that right?"

"Yes, boys, right enough; for the bottle has nothing but molasses and water in it; and the man is thirsty, I suppose. I would not employ him if he brought a bottle of spirits out with him, for two reasons. In the 
first place, I think that I ought not to encourage a man who gets drunk, by employing him; for I would rather give my money to a sober man who will not spend it for rum and brandy, but will take care of his family: and, in the second place, a drunkard would not work faithfully without being watched all the time. I never knew a drunkard who was really and honestly an industrious man."

"See, Uncle Philip, how strong that man is; what a large spadeful of dirt he throws out!"

"Yes, I see, boys: do you think that men had the first spades in the world?"

"Ah! now you are going to tell us something about tools among animals: that is rood; we like to hear of that. What animal is it that has a spade?"

"Oh, a very common animal indeed in some parts of our country. The country people call it a woodchuk, and sometimes a ground-hog: its right name is the marmot; and as there are several sorts, ours is called the Maryland marmot, to distinguish it; but it is in New-York, Connecticut, New-Jersey, Pennsylvania, Virginia, and some of the other states, as well as in Maryland. This is rather 
a mischievous animal, and does harm to the clover-fields; but it is in making his house that he uses his spade."

"Then he digs his house in the ground, Uncle Philip?"

"Yes; he burrows, or digs his nest in banks of earth, or on the sides of hills; and he has sense enough to make the passage to the inside upwards, instead of downwards, so that water cannot run in. In digging soft earth he uses his fore-paws to loosen the dirt, for his fore-legs -are very strong; and if the ground is hard he will use his teeth too. As he gets farther in, he throws the dirt with his fore-paws under his belly, and when he has a heap gathered, he balances himself on his fore-feet, and begins to throw it out with his spades."

"What are his spades, Uncle Philip?"

"His hinder feet, boys, which are very broad, and just fit to take up the dirt as a spade does, and to throw it from him: there is a skin which grows between the toes of his hinder feet, so that he can spread them out when he chooses, like a duck's foot."

"But, Uncle Philip, perhaps they are made so for the sake of swimming; the duck's are." 
"That is a sensible thought, boys. Always think for yourselves; and when you make a mistake, try again: everybody is mistaken sometimes. Let it teach you to be modest and humble; but do not be afraid to think again. A person who is always thinking cannot always think wrong. Now you suppose the marmot's feet may be made like a duck's for swimming: let me tell you something else, and we shall see what you will think then. The marmot hates a rain as much as you would if you had no umbrella; he very seldom even drinks water, and then only a little; and you cannot drive him into a stream or pond; he is afraid of it. What do you think now?"

"Why, Uncle Philip, we think that he is no swimmer."

"Very true, boys: so his feet, then, you now think, were made for spades, and not for paddles?"

"We do. Can you tell us any thing more about this animal, Uncle Philip ?"

"Oh yes. 'The burrows or holes of the marmot run a great distance under ground, and end in several chambers or rooms, according to the number that is to live in them. 
They make beds in them of dry leaves, or grass, or any thing soft and dry which they can find. They cram their mouths full of it to carry, when they are making their nests. As soon as cold weather begins, the animal goes into his house, and stops up the hole on the inside; and there he stays till the warm weather has come again.

"He is quite a thief at times. I saw one once which a gentleman had tamed, and he played about the yard; but every thing that he could get hold of which was fit to make his bed of, he was sure to steal, and carry into his hole under ground. When clothes were hung out to dry he would take them off the line, and as soon as any were missed the washerwoman knew very well where they were. She kept a long stick with a hook at the end of it, and with this she drew them out of the burrow. He soon found out what it meant, and whenever she used the stick, it was necessary first to tie him up; for he did not choose to have his bed spoiled, and would run to the hole and try to get in, and prevent the clothes from being drawn out. One day he stole eight pairs of stockings, a towel, and a little girl's frock; and he carried them into 
his burrow as far as six feet from the elltrance.

"But, boys, as we have begun this morning upon the old subject of tools among animals, I will tell you of something which, though not exactly a tool, is a very useful instrument, and is found belonging to a very common creature. Did you ever take notice of a bat?"

"Oh yes, Uncle Philip, often, as they were flying about in a rooin at night, but not nearer."

"Then you never saw what I mean, I expect. Our common bat, boys, has two very excellent hooks; one on each of what you call its wings: I say what you call its wings, because the bat is not really a bird, but a quadruped; that is, an animal with four feet : and when it is on the ground, any one may see that it is a four-footed animal. If a monkey's paw should be flattened out very much, it would be something like a bat's paw or hand. The long finger-bones are just like the sticks of an umbrella; there is a thin skin between them, and they stretch it out, so that the air underneath will keep them up. When they are on the ground all this is folded up. 
Their hinder feet have five toes, all small, and ending in sharp claws. On the fore-feet there is but one finger which the bat can use much, because the others are like umbrella-sticks, as I told you; and the end of that one is a hook. Here is a picture, in which you can see it plainly.

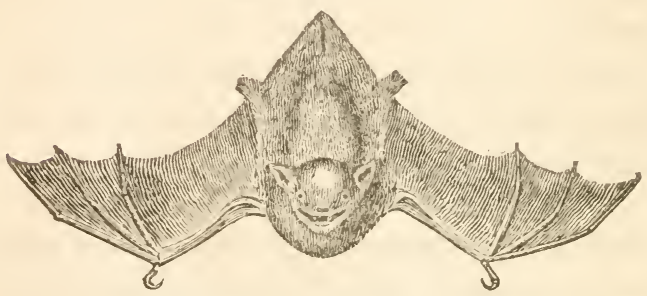

When the bat is on the ground, it is hard work for it to get along. At first it will reach forward a little to one side the hooked end of its fore-leg, and stick it in the ground; then it draws its hind-legs under its belly, and raisingitself up, just tumbles forward its whole body. At the next step it stretches out the other fore-leg, and hooks it, as it did before, and drawing itself up, tumbles forward again. 'The bat does not like a level place, because it cannot raise itself in the air from it. When they rest, they hang by the hooks; and here 
is a drawing of one, resting. In the other picture which I showed you just now the bat was flying."

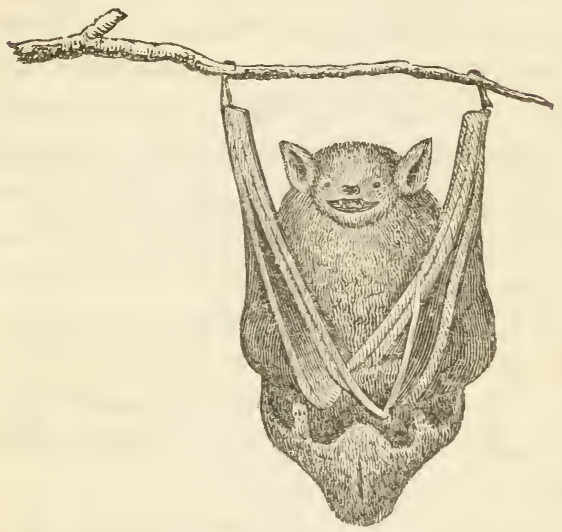

"Uncle Philip, we did not know before that bats were such curious things; we always thought that they were birds; but if these pictures are like them, these hooks are as good as fish-hooks."

"The pictures, boys, are very much like the animal, and the hooks are just as plain as they seem to be in the drawings. But how often do you suppose that you have seen a bat?" 
"Oh, many hundreds of times; for they are very common."

"True, boys; and yet you never lnew before that they had hooks about them. Suppose that everybody had done as you have, just passed by the bats, without taking notice of them; 1 could not have told you then what strange creatures they are, for no person would have known any thing about them. You see, then, that men may have eyes, and yet not see things; because they will not look for them. Use your eyes, boys; God made them to be used."

"But, Uncle Philip, bats are such ugly things! and they can bite, too. We are afraid of them."

"Ugly, boys! And what of that? Will you look at nothing but what is handsome? If the bat could think and speak, I expect he would call you very ugly. But it is foolish, boys, to be afraid of these smaller animals. There are many creatures which might hurt you, and I would advise you to keep out of their way: but it is silly to be afraid of every poor little insect or animal which you see. I have seen a large boy cry when he saw a poor little caterpillar or big near him. Now 
there are very few insects, indeed, which can or will hurt you; and a great many of them you may watch without touching them at all. And I think that he is a wicked and cruel boy who kills every poor bug that he sees, merely because he is stronger than the bug. It would be a great deal kinder and wiser in the boy to notice what the bug was doing, for then he might learn something worth knowing."

"But, Uncle Philip, is it wrong to kill spiders?"

"Spiders ! Why, boys, the spider is one of the very last of these little creatures that I should wish to kill. There is not a more curious little animal in the world, nor one that will pay a man better for watching its motions. At some other time I will tell you all about spiders and ants, for I have noticed them a great deal : but now, just to show you how much you would lose if you should kill all the spiders, I will talk with you about a tool which man uses, and which he might have learned to make from a spider."

"Oh, do tell us; what is it?"

"The next time you go to Mr. Brown's, the silversmith, ask him to show you his plate H 2 
for drawing out wire. Tell him that I told you to ask him, and he will show it to you. You will see a flat piece of steel with holes made through it in regular lines, beginning with a large size, and growing smaller and smaller until the last is very small indeed.

"Now the wire is drawn through these holes ; beginning at the larger ones, and passing every time through the next smaller one, it stretches the wire out, until it becomes as small as the workman wishes it to be.

"The spider is a wire-drayer, too; for it has a contrivance to draw 'out its threads, and make them smaller or larger, as it pleases. If you will look at a very large spider, you can see with your naked eye, just at the end of its body, four, and sometimes six, little knobs like teats, with a circle around them. These are its spinners. Each one of these small knobs, inside of that circle, is so full of little holes or tubes, that Mir. Reaumur (of whom I told you before, you will recollect) calculated that a place no larger than the point of a pin had a thousand of these little holes in it. These holes are sometimes so very smali, that another gentle- 
man, ${ }^{*}$ who looked at spiders through a microscope very often, thought it would take four millions of the threads which came through those holes to make one thread as thick as a hair of his beard. Here is a picture of a spider hanging by a thread coming out of its spinner, or, as it is sometimes called, its spinneret."

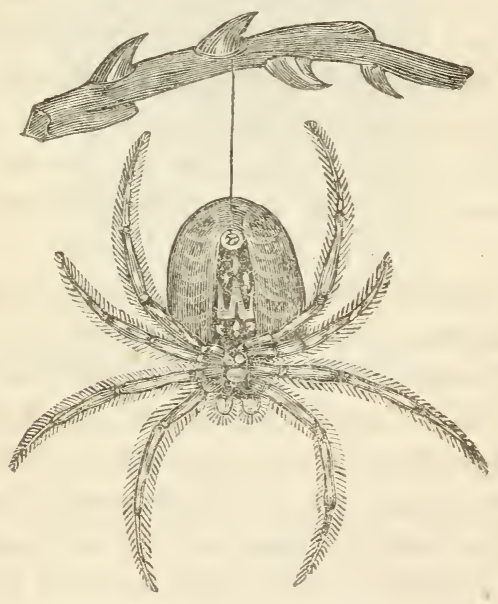

"Then, Uncle Philip, the spider does not spin its thread all at once?"

$$
\text { * Leuwenhock. }
$$


"No, boys. Fine as you see that thread to be, it is not one single line, but it is made of many thousands joined together. 'The spiders have little bags of gum within their bodies, near their spinners, and out of these they draw the threads: when they have come out about the tenth part of an inch, they join them all into one with their claws; and they can shut their spinners when they please, so as to make the threads longer or shorter; and they can break them off, too, when they wish."

"But, Uncle Philip, we do not see why there should be so many threads to make up one."

"I cannot exactly tell you, boys, why there are so many; but probably to make the thread dry quicker, by letting the air touch so many parts of it: and I expect, too, the thread is stronger, because we know that in two pieces of cord of one size, if one is made of several smaller cords put together, it will be stronger than the other, which was spun all at once. The following is a picture of the spider's spinnerets, and some of the threads as it appears through the microscope; only you must recollect that all the threads are not drawn: 
there are a great many more than you see in the picture."

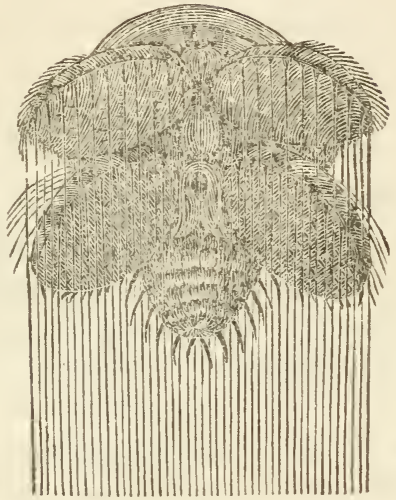

spider's Threads coming from the Spinnerets 


\section{CONVERSATION VIII.}

Uncle Philip tells the Children of a Door, with a Hinge and Spring to it, made by a Spider; and shons them Pictures to let them see the Difference between God's Work and Man's.

"I was thinking, boys, last night, of what you said about killing the poor spiders; and I was sorry that I did not then recollect one thing about a spider which I could have told you, and which would have made you like the poor little creatures better. However, I determined that when you came to see me again, it should be the first thing I would tell you, if you wished to hear it."

"Wish to hear it! Why, Uncle Philip, we always wish to hear you tell us of any thing that you please to talk about. You have told us of a great many strange things, about which we knew nothing before; and 
we will thank you to tell us the story about the spider."

"Very well, boys; you shall hear it. Pray, do you not think that it is a piece of difficult work to make a door to a house, and to make hinges to hang it with, and to fit it so nicely that when it is done you cannot see the joints where the door is shut?"

"Indeed it is a piece of very hard work, Uncle Philip, and it takes the carpenter a long time to do it ; and it is hard work, too, for the blacksmith to make the hinges. But what has that to do with the story about the spider?"

"Patience, boys, patience: you shall know presently. Never be in too great a hurry : it is a bad plan. I have always noticed that those persons who hurried most, went slowest in the end. Another question I wish to ask you is this,-do you not think it was hard work for the first man who ever made a spring, and put it on a door, to make it shut itself again when it had been opened?" "Yes, it was so: and the man who does it now gets well paid for it."

"Very good, boys. And now what will you say when I tell you that a poor little spider did all these things long before man did 2" 
"What, Uncle Philip! A spider make a door with a hinge and a spring to make it shut itself !"

"Yes, boys; a spider. Do you think he deserves to be killed for doing it?"

"Oh no, no! But pray tell us all about it, Uncle Philip."

"This kind of spider, then, boys, I saw in Jamaica, and I saw its house, too. It is called the mason-spider. 'The nest or house which I saw was a tube made of very hard clay, about six inches long, and an inch across, and was a little bent at one end. The inside of this tube was lined all the way through with a kind of soft silky stuff, something like silkpaper, but stronger, and it was of a yellowish colour; but the curious part was the door. I never saw any thing which an insect had made more strange than that. This door was round, about as large as a quarter of a dollar, and was a little hollowed on the upper side like a saucer; the inside of it was rounded like the outside of the saucer. It was of the same stuff with the lining of the nest, and seemed to be made of more than a dozen pieces of that lining, put one on the top of another: it was shaped so, too, that the inside 
layers or pieces were the broadest, and the - outside ones became smaller and smaller, except at the hinge, which was about an inch long. All the pieces in the door were joined into this hinge, and then the hinge was joined and worked into the lining in the tube. That made the hinge the thickest and strongest part of the whole work. How the spider made it so, boys, I cannot tell ; but so it was, that this hinge not only was a hinge, but was so good a spring, that whenever the door was opened it would shut itself immediately: and when shut, it fitted so nicely that it was very difficult to see the place of joining."

"Well, Uncle Philip, this is most wonderful! But will not the hinge wear out at last ?"

"Wonderful as it is, boys, it is all true. As to its wearing out, I cannot tell you; but I know that a gentleman who had one, said that his friends were very anxious to see it; and there were so many of them, that he had to open the door and let it shut itself many hundreds of times to satisfy them; and it did not hurt the spring at all."

"Uncle Philip, we shall not kill the poor spiders any more." 
"A good resolution, boys: only let them alone, and they will not hurt you. There is another kind of mason-spider, which I never saw, but I have read of it. It is found in the south of France; I did not happen, however, to meet with one while I was in. that beautiful country. 'This kind digs a gallery or hole under ground as much as a foot deep. She lines it with a sort of silk glued to the walls, and makes her door, which is round also, with many layers of mud or earth all kneaded and bound together with some of her silk. On the outside, the door is flat and rough, to make it appear like the dirt around it, and hide it; on the inside it is shaped like the inside of the door of the other spider I have told you about; and all covered with a coat of fine silk. The threads of this silk are left long on one side, and fastened to the upper part of the hole; and these make the hinge. There is no spring to this; but when the spider pushes its door open and comes out, it shuts again by its own weight. If this door is forced open by any one when the spider is at home, she will catch hold of it and pull it in; and sometimes even when it is half-opened, slie will snatch it out of the 
hand. Here is a picture which shows the nest open, and another of it shut; and there is a draving of the spider, too.

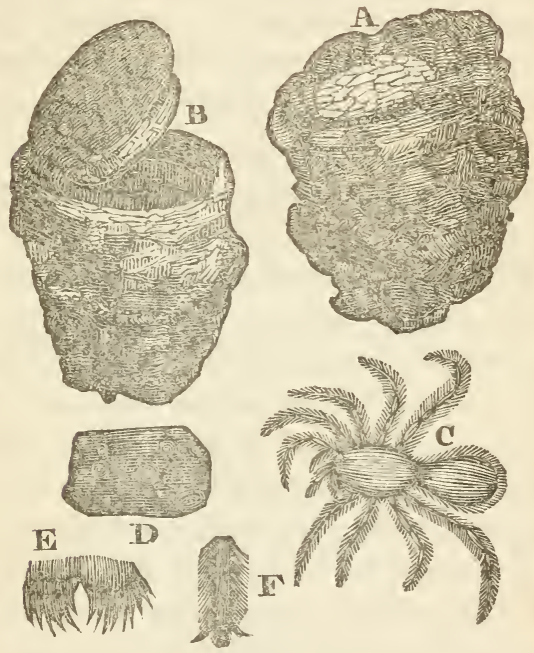

A, the Nest shut; B, the Nest open; C, the Spider ; D, the Eyes, mag. nified; E, F, Parts of the Foot a dd Claw magnified.

A gentleman says, in a book which he wrote about insects, that ree once broke one of these doors off, to see what the spider would do."

"And what did she do, Uncle Philip?"

"She made another door; but took very good care not to put any hinge to it, for fear 
she should be disturbed again. But when she thought all danger was gone, she could then put a hinge to it, you know; and probably she did." "Well, Uncle Philip, we thank you again for this account of the spiders, and shall always look at them hereafter with more pleasure. Who would have thought that we should ever find doors and hinges among such little creatures, and these too so very well made and fitted!"

"Why, boys, I have noticed the works of God very often; and I will now tell you one thing which $I$ always found. It is this: a piece of the very best work which man can make is really coarse when you compare it with the work of God. The poor spider that we have talked about, when she makes her door, makes it to fit perfectly; because in doing that one thing, God made her to know perfectly how to do it. 'The knowledge is God's, boys; but the work is the spider's: but in making any thing else, except about her house, the spider knows nothing."

"Uncle Philip, you told us once that you were very fond of watching all sorts of dumb animals, and we think now that we know the reason."

"Well, what is it?" 
"It is because you see so much of God's knowledge in them; is it not?"

"Yes, my dear boys, it is. When I look at many things which man makes or does, I think to myself, 'Now this thing is likely to have a mixture of sense and nonsense in it; the sense is God's, and the nonsense is man's.' But when I look at a thing made by one of the dumb creatures for its own comfort and safety, like the spider's house, with its door and hinge, for instance, I say to myself, ' Now here is the wisdom of God, without any of man's nonsense.' And yet, boys, men are far wiser than any other animal in this world."

"But, Uncle Philip, you said that a piece of man's best work was really coarse : some things must be neat, we should think. Is the point of a needle coarse? It does not seem so."

"Boys, you have mentioned the very thing which was in my mind when I spoke. The point of the smallest needle is very coarse. You have heard me talk of the microscope. I told you it was a set of glasses, so fixed that when you looked through them, it made small things appear very large : on some other day, perhaps, I will let you look through my microscope for yourselves; but now, I just wish 
to show you the difference between the work of God and that of man. Let us go home, and I will show you some pictures I made, and you can see in them the difference. Last winter, you know, was very cold, and there was a great deal of snow : one day, while the snow was falling pretty fast, I was obliged to go out; and as the flakes of snow fell upon the sleeve of my coat (which was black), I thought they had a curious shape, and did not all appear alike; so when I returned home I caught some of the flakes, and looked at them through my microscope. They were so beautiful that I made pictures of them; and as we have now reached home, just let me step into my study, and I will bring them to you. Here they are, boys."
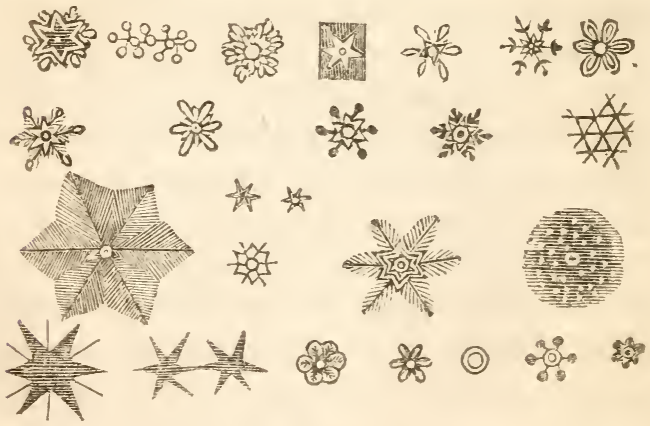

Snow-flakes, seen through a Microscope. 
"Oh, Uncle Philip! these are very pretty; they are all so different, too!"

"Yes, boys, I picked out different ones to draw : when I was done, I began to look into my books to find out what others had written about this thing; and I found that a gentleman named Dr. Hook had seen more than a hundred different shapes and sizes of these flakes. 'This is Gon's work, boys.

"Now I have brought you out another picture: it is the point of a very small needle, seen through the very same microscope which showed me the snow-flakes. Just look at it, boys. This is man's wrork."

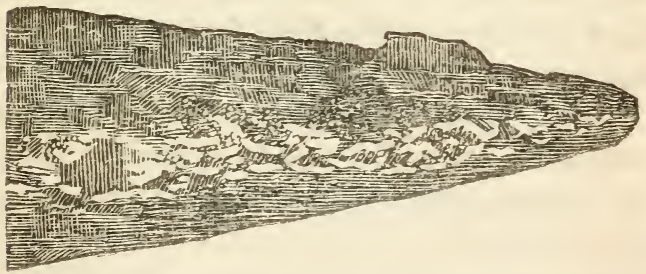

The Point of a very small Needle, seen through the Microscops. 


\section{CONVERSATION IX.}

Uncle Philip tells the Boys a Story about a Philosopher and his Kite.--He tells them, too, about Ants that have Awls, and build Cities, and Stairs, and Bridges, and many other things.

"So, boys, you have come again to see me. I am very glad of it; for as this is a leisure day, we shall have time enough to talk: but what is that you have there? Oh, I see now; it is a kite."

"Yes, Uncle Philip; it is a French kite that we have been making, and we have come to ask you to go out with us this morning and see us fly it."

"Very good, boys; I will go. I am an old man now; but I remember that I was a boy once, and loved to make a kite sail. It always makes me happy to see boys and girls playing about in health, provided they are not wasting time, and their play is not to do harm 
to anybody or any thing. So come on; we will go out upon the green common yonder, behind the church, and I think we shall have a grand kite-flying, for the wind is about right.

"There, boys! up she goes! Let out the string. I think she behaves very well ; there, she is done pitching about: now she is steady; see how she mounts. Ah, that is a very good kite."

"Uncle Philip, I was reading a book yesterday which said, 'A philosopher once found great help from a kite.' What did it mean?"

"Do you know what a philosopher is?"

"Yes, Uncle Philip; a philosopher is the same thing with a very wise man, is it not?"

"That is pretty near the meaning. Philosopher means a person who loves wisdom; and such a person, you know, will always be trying to get knowledge; and a person who is alvays trying to get knowledge is apt to be a wise and learned man."

"Well, how could a kite help a man to get learning? Did he read the old newspapers it was made of? I cannot see any other way."

"But there may be another way without your seeing it, you know. The philosopher 
whom your book meant was Dr. Franklin. Did you ever hear of him ?"

"Oh, yes; he was born in Boston, and was a printer, and afterward became a very great man."

"That is true. He was a man of excellent sense, who both read and thought a great deal; and in the war which the people of this country had with England to get their freedom, Dr. Franklin's sound sense was of great use to his countrymen."

"But, Uncle Philip, how did the kite help him?"

"I will tell you. If you take a proper piece of glass, or sulphur, or sealing-wax, or rosin, and rub it for some time, and then hold it near to small bits of thread or paper, the thread or paper will fly towards the glass or sealing-wax, and stick to it for a short time. That which makes them fly to the glass and stick there, is called electricity. After this was found out, men went on slowly finding out more and more, until at last a man named Hawksbee made a large machine with a glass barrel, which could be turned around by a handle like that which you see to a grindstone; and with this machine (which I will show you 
at some other time) he managed to get a great deal of this electricity, and it would shoot off in sparks, which appeared like little lightning. "And now, boys, what I am going to tell you will show you the use of a man's eyes. Dr. Franklin knew all about the electrical machine, and was very fond of drawing off the sparks from it, to see what he could find out about it. And when he saw it appeared so much like lightning, and could feel too a spark strike his hand a smart blow, he began to think that perhaps it was exactly the same thing with the lightning which came from the clouds; so he determined, if he could, to find out whether it was or not. He was a great deal troubled for some time to know how he should get down any of the lightning from the clouds; until at last, one day, he saw a boy flying a kite; and that showed him the way. So he took a large silk handkerchief, and stretching it upon sticks, soon made his kite; and not long afterward, when he saw a black thunder-cloud coming up, he took his kite and walked out of Philadelphia (where he then lived) into the fields, and sent his kite up. He had a string like yours, made of hemp, and to the end of this he tied an iron 
key, and then fastening it to the post of a shed by a silk cord, which he tied to the end of the hemp string, he got under the shed, and waited a long time. Now, boys, if he had been impatient, all his work would have been of no use. But he even waited, after a very heavy cloud had passed over his kite without giving it any of its lightning. At last, when he was almost ready to give it up and go home, he saw some loose threads on the hemp string rise and stand up straight, just as he knew the electrical machine would make them do. He directly put his knuckle to the iron key, and off came the spark, which he knew at once was exactly like the spark which he could get from the machine. And so, boys, he found out what he wished to know ; and this was the way in which the kite helped the philosopher."

"Well, Uncle Philip, this is really a very pretty story about Dr. Franklin and his kite. Was anybody with him?"

"Nobody but his son; he took him out to help him raise the kite. But, boys, I see the other lads are walking on towards the bridge with our kite; let us follow them, and as we go, I will tell you of an electric animal." 
"Oh, we shall be very glad to hear of him."

"Listen, then. There is a kind of eel, which when it is touched will give a very hard blow, just like an electric shock, to the person who touches it."

"Is there any spark, Uncle Philip?"

"No, boys; there is no spark,-but the blow is tremendous. I remember reading of one of these fish which was caught in a net, and a foolish sailor would take it up, though he was told it would hurt him. The fish shocked him so violently that he fell down in a fit, and it was a long time before he came to his senses; and his story was, that the moment he touched the fish, 'the cold ran swiftly up his arm into his body, and pierced him to the heart.' The fish has this power to defend itself, and to kill other fish for food."

"But, Uncle Philip, how do they ever manage to catch them alive? I should think they would be shocked to death."

"I will tell you. A very sensible traveller and learned man* gives an account of the manner in which they catch them, by a way called, by the South American Indians, ' fishing with horses."

* M. Humboldt. 
"Fishing with horses! What does that mean?"

"The savannas, or large open plains, in South America have a great many wild horses and mules running over them. M. Humboldt says that the Indians caught about thirty of these, and drove them into the pond where the electrical eels were. The horses made a great noise, and stirred up the mud with their hoofs, and this brought up the eels from the bottom in a great rage. They were very large, and looked more like water-snakes than like eels; and rising to the top of the water, they crowded under the bellies of the horses and mules, and began to shock them. The poor horses would try to get out of the pond; but the Indians, with spears and long reeds, would stand around to hinder them from coming out: some of them, too, would climb upon the trees around the banks, and get out upon the branches which were over the pond, and by crying out aloud, and using their long reeds, kept the horses in the pond. The eels would continue to shock them with tremendous blows, and a great many of the poor creatures were either stunned or killed, and would sink. Those not killed would parit 
and raise their heads, while their eyes would show their pain, and they would try to get out. The Indians still drove them back, but some few escaped, and reached the shore, stumbling at every step, and would stretch themselves on the bank, tired out, and benumbed in their limbs by the shocks they had received. M. Humboldt says that in less than five minutes after the fight began, two horses were drowned; and he thought that the end of it would be, that every horse which did not get out of the water would be killed : but at last the eels became tired, and began to disperse. This is just what the Indians wish. They know that the eels have spent so much of their electrical power that they will need a long rest. It takes them a great while to get back their strength; so that if, the next day after such a fight, you send in more horses, they cannot kill one. When the eels, tired out in this way, begin to separate, they will swim to the edge of the pond, and there the Indians take them with small harpoons fastened to long cords. When the cords are dry, the Indian feels no shock in raising the eel out of the water. In this way 
M. Humboldt got five, all alive, and very little, hurt. But here we are at the bridge."

"Uncle Philip, suppose we sit down under the shade of this tree, and rest."

"I am willing, boys; but take care of the damp ground: there is an old piece of timber that the men have taken out of the bridge, for I see they have been mending it; we will sit on that."

"But, Uncle Philip, what shall we do with the kite? shall we draw it down?"

"Do with it! Why, just tie the end of your string to that root, and it will take care of itself in this wind."

"What a monstrous piece of timber this is, Uncle Philip! It must have taken a great many men to move it; and see-there are some larger ones still in the bridge. It must be a difficult work to build a bridge."

"Yes, it is so: but there are bridges much harder to build than our little wooden one here. Some are built of stone, and it takes years to finish them. None but a good workman can plan and build a good stone bridge: but I know a little fellow that can make as good a bridge as anybody; and yet no man ever taught him the trade." 
"Ah! now we know what is coming. You are going to tell us of a dumb animal that can make a bridge."

"Yes, I am : and a small animal it is, too, for it is an ant."

"What sort of an ant is it?"

"It is called the white ant; and as there is a great deal that is very curious about this insect, I think that I had better tell you all about it at once."

"Pray do, Uncle Philip; you know you promised to tell us about ants."

"True, boys; and I like to keep my promises. In my story about these ants, I think, if you attend, you will find more tools; and besides that, you will hear of a great many things which man makes, and which show matters quite as strange as any of which I have yet told you."

"What are they, Uncle Philip?"

"They are the building of something like a city, and bridges, and stairs, and roads, and tunnels under ground, and-"

"Oh, let us hear-let us hear! We have heard nothing equal to this yet."

"Well, then, I begin by telling you that these insects are very common in Africa, $\mathrm{k} 2$ 
and in the East Indies, and are troublesome enough, for they eat almost every thing but metal and glass. They love wood, though, better than any thing else; and they are so numerous that they destroy it wonderfully fast. They are very cunning, too; they never eat the outside of the wood first, but will work upon the inside, so as to leave the outer part not thicker than a piece of pasteboard. But the curious things I meant to tell you were about their city; so I will go on to that. When they first begin to build you will see little hills shaped like a sugar-loaf, and rising up above the ground about a foot, or a little more. Here is a picture of them.

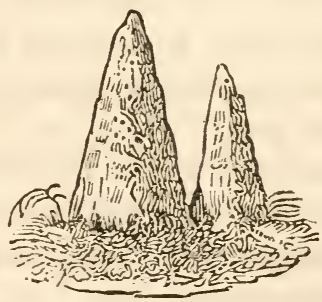

The highest of these little hills is always in the middle; and they go on building more and more, and making them all higher, still keeping the tallest one in the centre. When 
they have made them as high as they wish, then they fill in the spaces between the tops of all these sugar-loaf hills, so as to make one roof over all. Here is a picture of one finished.

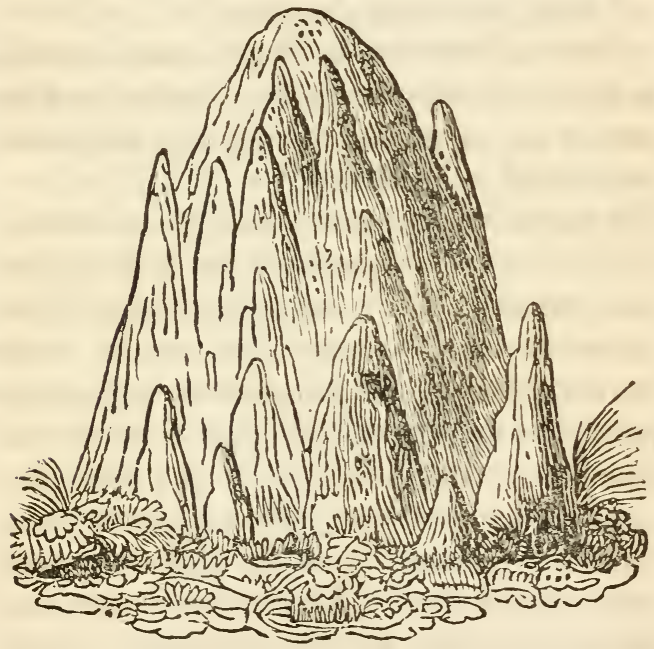

After this is done, they take down nearly all of the little sugar-loaf hills inside; for they only wanted them for a scaffold to support the top while they were building it."

"Uncle Philip, what is all this built of ?"

"It is built of clay, which the ant makes almost as hard as stone." 
"Are they strong, Uncle Philip?

"So strong, boys, that five men may stand on them; and it is a common thing for the wild bulls to get upon them and look out, while the rest of the herd are feeding below."

"Why, how high are they?"

"Oh, of different heights; some as many as five or six feet, others are twelve, and the largest are as high as twenty feet, and would easily hold a dozen men."

"And how large are the ants, Uncle Philip?"

"Not above a quarter of an inch high as they stand. Now, boys, just compare the size of one of these nests with the size of the ant that made it ; and it is quite as large in proportion as the city of New York is when compared to a man's size; yes, it is a great deal larger in proportion. These nests are sometimes five hundred times as high as the ants which build them: now suppose that men built their houses five hundred times as high as themselves, and as large at the foundation in proportion to their height, what monstrous buildings they would be! But let me go on. This outside shell, which I have been telling you how they make, is nothing but the wall of the city; the buildings are all inside of that." 
"But, Uncle Philip, there is one thing I have been thinking of which would make it more like a city still. But I hardly think they can have that."

\section{"What is it?"}

"Wly in a city, you know, where there are a great many people, there are a great many trades: some do one thing and some do another to get money."

"Yes, that is true; and I am glad that you mentioned it, because it reminds me of one thing I intended to tell you about these ants. Now, it would not be reasonable, you know, to expect the ants to have many different kinds of business to do, as the people in New-York have; but still, boys, they are not all alike, and they do have work of different kinds. There are in the city of the white ants a king and a queen, and soldiers, and labourers, or workmen, and all these are different. Here are pictures which will show them all to you. This is the king.

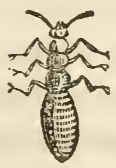

King of the Termites. 
At first he has four wings, but soon loses them. He never grows any larger after he loses them. The king may be known by his having two large eyes. Here is the queen. She is the mother of the whole city; and you see what a large body she has. It is full of eggs, and eighty thousand will come from her in twenty-four hours. She also has two eyes.

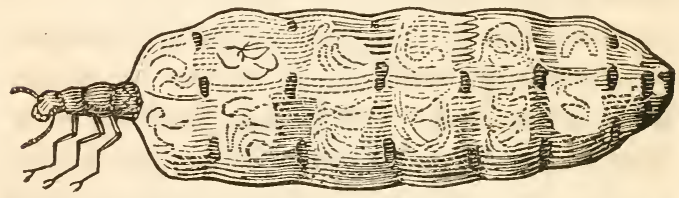

Queen of the Termites.

"Here is a soldier: he has a large head, armed with two hooks, shaped like a crooked awl, and very sharp.

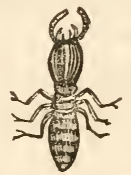

Soldier of the Termites.

"For every one of these soldiers there are about one hundred labourers. The soldiers do the fighting; and though they are perfectly blind, they fight well, and are very brave. 
The following is a picture, too, of the soldiers' awls, seen through the microscope, to show you how sharp they are.

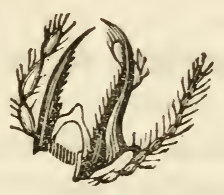

"And here is a picture of the labourer; the largest part of the city is made up of the labourers,-which shows us, I think, boys, that there is more need of working than there is of fighting.

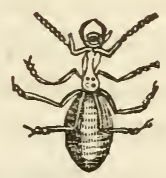

Labourer of the Termites.

This class, like the soldiers, is blind, and scarcely ever go into the open air ; their work is mostly under ground or in the inside of wood. Both, however, do come out when their city is attacked and broken: but I will tell you of that presently." 


\section{CONVERSATION X.}

Uncle Philip tells the Children more about the White Ants.

"Now, boys, as I have told you about the kinds of different work which these ants do, we will go on, and I will tell you about the inside of the city. The first thing to be done is to build a house for the king and queen. This is the first house built in the city, and always stands in the centre, directly under the point of the roof or top of the outside wall. It is built nearly on a level with the 'ground, and is shaped very much like a long oven, or the half of an egg split through the long way. The floor is exactly level, and about an inch thick; the roof is about the same thickness. The doors are on a level with the floor, and just large enough to let one of the labourers go in."

"Why, Uncle Philip, how do the king and queen ever get out then." 
"They never do get out, boys; they live in that house always, and they are not the first kings and queens who have found that a palace is sometimes a prison. Just around this house of the king and queen are other houses built of clay, arched at the top, and of different shapes. These are for the servants or labouring ants, who remove the eggs of the queen as fast as she discharges them. The soldiers also live in these houses. Next to these are the magazines, that is, the houses where they keep their food, such as dry juices of trees and gums; and mixed up with these are the nurseries. These are made by the labourers, and are different from all the other buildings, for they are made of wood gnawed or broken into fine threads, and joined together with some kind of gum, and around each of them there is a case of clay. These nurseries are to carry the eggs into for the young ants to be hatched. Between all these different houses or parts there are thousands of galleries or ways, which run among them and separate them from each other, and these may be called the streets of the city. These streets run in all directions, and extend as far as the outside wall; and houses are built on 
top of houses, and streets run over streets, until they reach up as high as two-thirds of the inside wall. But under the top of their outside case they always leave a large open place that is never filled up with houses. And around this space they will build three or four large arches, sometimes two or three feet high; these I suppose are to prevent the houses from falling in towards the centre of the city, which is an open space, and on the other side they are fastened to the outside walls, so that these houses are very firm."

"And what is all this made of, Uncle Philip?"

"All of clay, except the nurseries, which I told you were made of wood and gum. Over the house of the king and queen there is a sort of flat floor, some distance above it, with nurseries and magazines between the under side of it and the top of the queen's house. This floor will not let the water through it, so as to wet the palace where the king and queen live, but will turn it off into large trenches or gutters under ground, of which I will speak directly. 'The bridge I told you of they build from this floor in the open space, directly under the top or dome of the 
outside wall; it rises up and is joined to some hole in the side wall of the houses above it."

"How large is it, Uncle Philip ?"

"Why, sometimes it is half an inch broad, a quarter of an inch thick, and ten inches long; all made of clay, so that it is very strange how they manage to join it to the wall without its falling down by its own weight while they were building it."

"And what do you suppose this bridge is for, Uncle Philip ?"

"Why, I think there can be no doubt what it is for. When the city has been growing for some time, some of the nurseries will be very high up above the queen's house ; but the labourers have to carry her eggs into them, no matter how far off they may be. If they carry them through all the streets, they will have to walk as many as fifteen or twenty feet, for it would be five or six feet in a perfectly straight line, and these streets are very crooked; but if they make a bridge in the open space in the centre, they can then go from the queen's house over the bridge, and get to the upper nurseries without travelling more than two feet. So they made the bridge to shorten the way, to be sure." 
"This is very wonderful: but you said something about large trenches or gutters underground; what are they, Uncle Philip ?"

"These galleries lead from the city under ground, and are as large as the bore of a large cannon; they are thirteen inches across, and more than a hundred yards long. I have already told you that the labourers never come out into the light when they can help it; and these underground ways are the great roads to the city, to fetch in clay, or wood, or water, or provisions: and now I will tell you another thing which shows a great deal of sense. As some of their houses are very high up, you know they would find it very hard to climb up through all the streets with a heavy load in a straight line; so when these large ways underground reach the outside wall, they just come through and keep on winding around the inside of it like a corkscrew all the way to the top; and there are other galleries opening from it at different places into the city. One thing has been noticed about these ants; they can scarcely climb at all up a perpendicular wall. Therefore on the upright side of any part of the city you may see a road made, standing out from the wall like 
a ledge; it is flat on the top, and half an inch wide, and goes up gradually like a staircase, or like a road cut out on the side of a mountain.

"Here is a picture of one of their cities cut straight down through the middle. At the bottom, in the centre, is the queen's house; over it is a floor, and the two crooked things vou see rising up from the floor, are bridges."

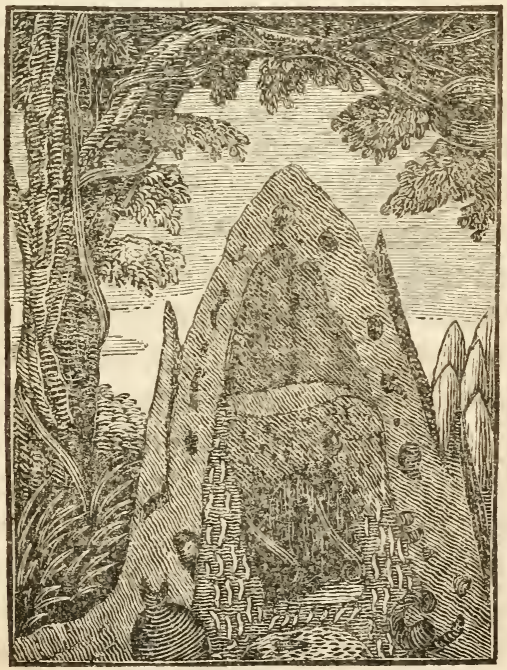


"But, Uncle Philip, your said you would tell us about the soldiers and labourers coming out when the city is attacked."

"Yes, I did. As soon as a hole is made in the outside wall, you will see a soldier run out, and walk about as if to look around; but as he is blind, it cannot be to see what the danger is. He may have some way though of finding out without seeing. Presently he will go in, as if to tell the others, and then out pour the soldiers in great numbers, as fast as the hole will let them; and just as long as you strike the outside wall, they will continue to rush out. They seem to be in a terrible passion. They are in such a hurry that sometimes they slip, and roll down the outside of the hill; but they jump up again instantly, and begin to bite every thing they run against, for they are blind and can= not tell a friend from an enemy."

"Do they bite hard, Uncle Philip?"

"Very hard indeed. They make their hooked jaws, which are like awls, you know, meet at every bite; and if it should happen to be a man's leg they get hold of, you would see upon his stocking a spot of blood an inch long. At every bite too you may hear their jaws 
snapping together and making quite a noise. Some of them too (perhaps they are the officers) are constantly beating with their awls upon the outside wall, and make a sound something quicker and sharper than the ticking of a watch. You may hear it at a distance of three or four feet. When these biters lay hold, nothing will make them let go; you must tear them away by pieces. After you stop striking the wall, in about half an hour they seem to get over their rage and go back into the city, and then out come the labourers. While the noise continues you will not see one of them; they all fled at the first appearance of danger. But now they come, each one with a bundle of mortar in his mouth, ready made; and they stick it on the hole so fast, and with such order, that though thousands and thousands are at work they never interrupt each other. And while the labourers are busy, if you look you may commonly see a soldier or two walking about; but they never touch the mortar, nor help in any way to mend the hole. One of these soldiers always stands near the spot where the labourers are at work, and every now and then turns slowly around, and frequently lifts up his head, and with his awls 
beats upon the building, and makes a sort of hissing noise. As soon as that is done you may hear a loud hiss from all the labourers, both on the outside of the wall and from the inside of the city, and then the labourers run faster, and work as quick again. If you attack the nest again, away run all the labourers as fast as their legs will carry them, and out pour the soldiers as before; and the same thing is always seen upon every attack, of soldiers to fight and labourers to work."

"Well, Uncle Philip, this is a very strange story; much more interesting than any we have yet heard."

"I thought it would please you, boys; but there are still stranger things among animals, and perhaps you will say so when you know more.

"But it is now time to return home; so take in the kite and let us be going." 


\section{CONVERSATION XI.}

Uncle Philip tells the Children about some other Ants, that are very good Masons, and build Walls and Ceilings; and a story about a very sensible Ant, which seemed to think a little.

"Groos morning, good morning, Uncle Philip; we have been so much delighted with the stories about the white ants, that we hope you have more of the same kind to tell us."

"Why, as to that matter, boys, I can tell you much more about ants, for there are many kinds of them; but I am not sure that I can show you any of the tools with which they work, though a large portion of their work is like that of man; and they have, too, several customs which our fellow-creatures have. I can tell you, however, of several other animals which do use tools shaped like those used by men, if you would rather hear of them." 
"If you please, Uncle Philip, we will hear of them at another time; but now we would rather have you tell us of the other kinds of ants."

"Oh, very well, boys; it shall be as you wish. All that I desire is to instruct and amuse you, and $\mathrm{I}$ am sure that the ants can furnish a good lesson to us. I shall begin with the mason ants. They always build their nests either of clay which is damp, and dug from the inside of their city under ground, or which has been marde wet by the rain; and a part of their building is always above the ground, so that you can easily see it. 'There is no fixed rule for the ants to build by. Their cities are not all alike in the inside. Sometimes the walls are larger and coarser, and the ways and galleries are higher, than at other times. The rooms, too, are different in shape and size, so that this industrious little insect seems to have sense enough to work in the best way according to circumstances. There is only one general rule which they seem to have, and that is always to build in a number of different stories, one above the other. If you examine one of these stories you may see a number of large places or halls, some smaller rooms, and some long galleries which 
serve as passage-ways. The tops of these large halls are covered with an arched ceiling, and this ceiling is held up, sometimes by little columns, sometimes by very thin walls, or by props built against the side walls, just like buttresses. There are also chambers which have but one door, which opens into the lower story, and large open places in the centre of the nest something like a cross road, and all these little galleries or streets come into that open place."

"Any bridges, Uncle Philip?"

"No, boys; no bridges among these ants, so far as I know. There will sometimes be as many as twenty stories above ground in the ant-hill, and as many below. The best time to see these little fellows at work is in a gentle shower of rain, or directly after."

"Why do they work in the rain, Uncle Philip ?"

"I suppose, boys, it is because the earth is then better for them; and one thing that has been noticed about their work is, that the rain, when it is not too violent, seems to make it solid, for these ants have no gum or glue about them like some other insects, to make the earth stick together. As soon as the rain 
begins, if you watch the brown ants, you may see them come out of the ground in great numbers; and then running in again, they will soon return, each one with a little piece of dirt in his mouth, which he puts down upon the roof of the nest. A gentleman who watched them very closely* says, that at first he could not think what this was done for, but at last he saw little walls begin to rise up with spaces left between them. In some places pillars were begun, placed at regular distances, and he knew that these were to support ceilings; so he found out that they were going to build another story to their house, and they were laying the foundations."

"How I should have liked to see them, Uncle Philip. I would not have cared for the rain."

"Ah, I see you are fit to be a naturalist. You know what that word means, do you not?"

"It means, Uncle Philip, a man who loves to study about the animals and insects, does it not?"

"It means a man or a woman either, boys, who loves to study the things in nature no

* Mr. Huber the younger. 
matter whether they are animals, or stones, or grass, or flowers, or any of the things which God has made. Mark, boys, I said to study the things, and you said to study about the things. Now a person may read a great deal that is interesting and true about all these things in books; and it is very well to do so; but I think that the real naturalist will never be satisfied with books only; he will be looking to see things for himself. And I said a woman might be a naturalist, because some ladies have been fond of natural history, and have proved themselves to be very good naturalists. But let us go back to the ants. Mr. Huber, in the account which he gives of his having watched these little workmen, never thought of telling us whether he got wet or not, because he was too busy to think or care much about it. He had an opportunity of seeing. what he might never see again, and a little rain was not to spoil it. He says that each ant, as it brought out its little lump of dirt, would place it on the spot where it wished it to be, and press against it with its teeth, so as to make it fit closely. It then rubbed its feelers all over it, and after that pressed upon it lightly with its fore-feet. 
The walls went on very rapidly, and it often happened that two little walls, which were to make a passage or gallery, would be raised opposite and at a small distance from each other. When they were about a quarter of an inch high, the ants would set to work and cover them with an arched ceiling. After they had raised all the walls as high as they wished, on the inside of each wall at the top they began to put in pieces of wet dirt almost level, and in such a way as to make a ledge; and by joining on more dirt to it, it would meet the ledge made from the opposite wall so as to make a roof: these roofs over the galleries were about a quarter of an inch across. The ceilings over the large halls were sometimes as much as two inches in breadth, and to support these they raised pillars; and beginning in the corner where two walls joined, they would commence the ceiling with a ledge, while from the top of each pillar they would also build out a layer of earth a little rounded on the top; these they continued to add to until all met and made a complete cover for the hall."

"I wonder it did not fall, Uncle Philip, before they could join it together." 
"Mr. Huber says that he thought several times it would fall, from the rain which was dropping upon it all the time; but he found that the pieces held together, and that the rain, instead of hurting it, only made it more solid. All that it wants, when the ants have done, is a little heat from the sun to bake it hard, and then it appears like a piece of solid dirt. Sometimes, if the rain be violent, the apartments will be destroyed, especially if the arches are not built strongly; and when this happens, the little creatures go to work very patiently and rebuild them."

"And how long, Uncle Philip, did it take the ants to put another story on their house?"

"Between seven and eight hours; and they had hardly finished one before they began another, but they had loot time to finish it, for the rain stopped before they had built much: however, they kept on, taking advantage of the wet earth; but a cold drying wind soon sprang up, and the earth would not stick; so they stopped: but what do you think they did with the new story which they had not time to finish?"

"What did they do, Uncle Philip?"

"Pulled every part of it to pieces, and 
tered the dirt here and there over the roof of the story which they had finished.

"I will tell you another story about these ants, boys, which I think is most wonderful, because it appears so much like reason. These insects all seem to work separately,-I mean without attending to the work of others: of course sometimes the work done by different ants on opposite sides of the same gallery or hall will not suit: one wall will be higher than the other, so that the ceilings will not meet. Mr. Huber saw just such a case; the ceiling which was begun from one wall would just have reached the other wall about half-way up; and while he was wondering how the ants would cure the fault, one of them came, and looking at the work, seemed to know that it was wrong, and immediately began by taking down the ceiling from the lower wall; he then raised it to the same height with the opposite wall, and made a new ceiling in Mr. Huber's presence with the pieces of the old one."

"Uncle Philip, if that ant did not know how to think, I am mistaken."

"I must confess, boys, it does seem very much like thinking; and if it was not think- 
ing, we must at any rate own that it was something which, in this case, did quite as well; for no thought of man could have hit upon a better plan. But if the ant knew how to think as a man does, do you suppose it would ever have made the mistake? Would not the workmen have all agreed beforehand what they were to do, and liow it should be done, so that there might be no need of pulling down any of the work because it would not suit? I think that this story, boys, while it shows us something like reason in one particular instance, shows us also that in general the ant has not reason like ours. But I am tired now, and can tell you no more this morning. When you come again I shall be ready to talk with you about some other kinds of ants. But before you go, tell me-can any of you inform me what the Bible says about the ant?"

"Oh yes, Uncle Philip : it says, 'Go to the ant, thou sluggard, consider her ways, and be wise." "

"Well, another question. Have you any lessons to say when you go into school on Monday?"

"Yes, Uncle Philip; we have." 
. "Have you learned them, boys?"

"No, sir."

"Then remember what the Bible says to the sluggard, and go and learn them at once. Good-by, children."

"Good-by, Uncle Philip : we will learn our lessons."

\section{CONVERSATION XII.}

Uncle Philip tells the Boys about Ants that go to War and fight Battles; and about some that are Thieves, and have Slaves.

"WELL, my lads, how do you do to-day?"

"Very well, Uncle Philip, we thank you. And we wish to let you know that we kept our promise to learn our lessons. Our teacher was very well satisfied with every one of us."

"That is well, boys. I am truly glad to hear this from you: and I make no doubt that you also felt a great deal happier than you would have done had you neglected to learn your lessons. Did you not?" 
"Oh yes, Uncle Philip, much happier; and "far more cheerful and good-natured."

"Such are apt to be the feelings, boys, of those who have done their duty. I am verily perstuaded that there is no such thing as real, solid happiness in this world, but in that man who acts from a sense of duty. His is true peace, because it is 'the peace of God.' I do not say, boys, that a man, even when he does his duty, always feels comfortable or happy at once; but he will be more apt to feel so than if he did not do his duty : and I do say that no man who does not act from a sense of duty, is likely to feel any thing like happiness very often or very long."

"Then, Uncle Philip, a man who wishes to be happy will try in the first place to find out what his duty is."

"To be sure, he will; and he need not try very long either, if he really wishes to know it. The will of God, boys, is at the bottom of all our duties; and an honest man, yes, or boy either, can commonly tell what God will think to be right or wrong in his conduct. You know where a great many of our duties are very plainly written down for us; do you not?" 
"Oh yes, sir; in the New Testament, which tells us of what our Saviour said and did."

"True. And what our Saviour commanded, boys, God commanded; for $\mathrm{He}$ is God. But besides this, when it is not exactly written down in the New Testament what we should do, still if we will think, we shall very often find out what to do, from what is written."

"Uncle Philip, we almost always know what you mean; bat now, we do not quite understand you."

"Thank you, boys, for telling me that you do not know what I mean: always tell any person who is trying to teach you something, when you do not understand what is said to you. Now I will try to make what I said plainer to you. The New 'Testament does not say any thing about your going to school; does it?"

"No, sir."

"Who sends you to school, boys, and pays your teachers for instructing you?"

"Our parents, Uncle Philip."

1 "Very well. Now suppose that John Carter here, should wish, instead of going to school, to do, what I am very sure he never did do: 
suppose he should determine to play the truant. The Bible does not say a boy shall not play the truant, does it?"

"No, Uncle Philip."

"But if John Carter should play the truant, he would, in doing so, disobey what God has commanded in the Bible just as. much as if the Bible did say 'A boy shall not play the truant;' for the Bible does say, 'Children obey your parents,' and he could not be a truant without disobeying his parents, who bade him go to school."

"Uncle Philip, we understand you verry well now."

"There is another thing I wish you to understand, boys. John Carter, as you see, would not only disobey his parents, which is wicked, but he would also commit a sin against God. That is always the thing to look at first. When we are going to do something that we are not very sure is right, we should always stop to ask ourselves whether God will be pleased with it. But I have said enough to you about our duty for this time. Now for the ants I promised to tell you of. And the first sort I shall mention are great fighters." 
"Fighters, Uncle Philip! What do they fight about?"

"About trifles, boys, just as men do. They have terrible wars, and will dispute with and kill each other for a few inches of dirt, when certainly this worid is large enough for them all. But animals wiser than ants, boys, act in the same foolish way. Men sometimes go to war and kill each other to determine who shall have a river, or a small town, or a fort, or some little spot of ground; while the poor creatures who do the fighting, and get all the wounds, and lose their lives, had they been let alone, would have lived on in peace, and never cared a straw who had the miserable little spot they fight for. But let me go on with the account of these ants. In the forests, where the fallow ants live, you may see these wars. The battle will be between the ants of different hills, but they are all ants of the same sort. Thousands and thousands of them will meet on the ground between their hills, and the battle begins by two ants, who seize each other by the claws (or mandibles, as they are called), and rising up on their hind-legs, they bring their bodies near 
together, and spirt a sort of venomous or poisonous juice upon each other. These will be followed by thousands of others on both sides, who seize each other in the same way, and fight in pairs-ant to ant. Sometimes they will get so wedged together that they fall down upon their sides, but they do not let go on that account; they keep on fighting in the dust until they rise on their feet again. Sometimes, too, a third ant will come in, and joining whichever of them belongs to his nest, the two will begin to drag the third, until some of his friends come to his help; and in this way, others joining on both sides, they will form strings of six, or eight, or ten on a side, pulling with all their strength. And while some are fighting, you will see others leading off prisoners towards their hills, while the prisoners are trying to escape. The field of battle is not more, perhaps, than three feet square; multitudes of dead ants covered with venom may be seen upon it, and there is a very strong scent which comes from it. When night comes they go off to their hills. Before dawn the next day they are at it again in still larger numbers, and they fight with greater fury than before, until 
at last one side or the other gives way. They are so busy that even if you stand near them they take no notice of you, and not one stops fighting, or crawls up your legs."

"Do all of them that belong to the hill go out to fight, Uncle Philip?"

"No; near the hills all is peace and order, and work seems to be going on as usual. Only on the side next to the battle, crowds may be seen running backwards and forwards from both hills; some as messengers, I suppose, and some to fight, or carry back prisoners."

"But, Uncle Philip, you said that these ants were all of one sort; how then do they. know one another so as to tell which party each one belongs to? I should think that sometimes they would make a mistake, and fight a friend instead of an enemy."

"This, boys, is one of the most wonderful things concerning them. They are alike in form, and size, and weapons, and strength; and sometimes it happens that they do make a mistake, but it is very seldom; and when they do, Mr. Huber, who watched one of their battles, says that they find it out directly, and 
caress each other with their feelers, and make up the difficulty at once.

"Are you tired, boys, or do you wish to hear more?"

"Oh, let us hear more, by all means: we are not at all tired."

"I will then tell you of another kind of . ants called legionary ants, and sometimes amazons; but I am sorry to say that they are unlike other ants, for they are lazy; and yet they live very comfortably."

"How is that, Uncle Philip? Can they be comfortable without working?"

"Yes, boys, if they can get others to work for them; and these have their work mostly done by their slaves."

"By their slaves! what are their slaves, and where did they get them?"

"As to your first question, boys, their slaves are ants of another kind; as to the second question-where they get them-they stole them when they were young."

"Why you surprise us, Uncle Philip."

"I dare say I do. There are persons much older than you are who have never attended at all to the doings of insects, who would be very much astonished by the history of the 
legionary ants; and probably would laugh as the whole account as an idle story; and yet it is all true, and those who have read and seen, know it to be true; and they know, too, that to deny it shows nothing but ignorance. However, I always let such persons alone. I can do them no good; for they are apt to be very conceited, and will not be convinced. And now for the legionary ant. This is a fighting ant, as well as the last I mentioned; and it actually steals the young of another kind, rears them, and puts all the work on them, so as to be idle itself. This curious fact was first found out by Mr. Huber; another gentleman, named Latreille, afterward saw the same thing; and now a great many naturalists know it, because they have sought for and seen it. The ant which it steals is of a dark ash colour; the legionary is of light colour. The dark-coloured ant is now called the negro ant, and is a very industrious, peaceable insect, without any sting. The legionary is a strong, brave ant, with a sting, but very lazy. I shall relate to you the account which Mr. Huber gives of the legionary. He was walking near the city of Geneva during an afternoon in the summer 
of 1804 , when he saw quite an army of these legionary ants crossing the road ; they passed through a thick hedge, entered a pasture, and kept on through the grass without separating; and Mr. Huber followed them until he saw them come near a nest of negro ants. Some of these negro ants seemed to be guarding the holes into their nest; but as soon as they saw the legionaries, they, with a great many more from the inside of the nest, attacked the thieves. The legionary ants, however, were too powerful for them, and after a short but severe fight they conquered the negroes, who ran into the lower part of their nests. The legionaries then mounted their ant-hill, some entered it by the holes already made, and others began with their teeth to break other holes, so that all the army might get into the hill. They went in and remained but a few minutes, when they came out, each one having in his mouth a young negro ant, and off they scampered, without any order among them, every one going his own way, until Mr. Huber lost sight of them. The next day he set out to go back and examine further, and on his way he found a large ant-hill full of legionaries, and saw an army start from it, 
which he followed. They made the attack as before, and each one came off with a young negro ant in his mouth, and on going back to their hill, from which Mr. Huber saw them start, he had an opportunity of seeing them return, and was very much surprised to find all around the nest of the legionaries a great many full-grown negro ants. At first he thought that perhaps they had gone there to fight the legionaries, but he soon saw that instead of fighting, the negro ants went out to meet the legionaries returning, and would caress them, and give them food, and finally take the young negro ants and carry them within the nest."

"But, Uncle Philip, why do the legionaries always take the young ones?"

"Because, boys, they know, I suppose, that the old ants would never be satisfied to remove from their homes; and therefore they take the young. These legionaries could work if they would, I think, but they depend upon the negro ants for house and home, and food too; and nothing can be more faithful and affectionate than these poor slaves are. To try them, Mr. Huber took thirty of the legionaries, and put them with some of the larvæ, 
or grubs of their own young, into a glass box with a thick coat of earth at the bottom of it, and he put honey also in the box, that they might not want fond. At first the legionaries paid a little attention to their young; but they soon stopped; and they neither tried to make a house, nor took any food, so that in two days half of them died. Mr. Huber then put in one negro ant, and this little creature set to work alone, made a chamber of the earth in the box, gathered the young together, fed the old, and put every thing into complete order.

"At another time Mr. Huber broke one of the ant-hills of these legionaries, to see how they would act, and in doing it, he, of course, altered their galleries and chambers. The legionaries seemed to be lost, and went wandering about, without knowing where to go ; but the negro ants appeared to understand very well where they were: they could find such of the galleries as were not broken, and would take up the legionaries in their mouths and carry them into them. If the negro sometimes seemed for a short time to be lost, and not to know where it was, it laid down its master, ran round and examined until it knew, and then would come back, and pick up the s 2 
legionary ant, and carry it off. In one case Mr. Huber saw that the entrance to a gallery was stopped up by a small lump of earth; the negro ant laid his master down, took away the piece of earth, and then carried him in."

"Why, these poor negro ants are sensible as well as faithful, Uncle Philip."

"Yes, boys, they are so ; and I think it is likely that both kinds depend in some way upon each other, but we have not yet found all about it. I expect that in some things the legionary does for the negro ant what it could not do for itself. God has made them necessary to each other, and this is the reason they live together so kindly.

"But I think it is time now to leave the ants, and go back to our business of seeking for something like man's inventions and tools among the lower animals. Perhaps hereafter I may tell you more about ants ; but at present I must bid you good morning."

"Good morning, Uncle Philip." 


\section{CONVERSATION X́III.}

Uncle Philip and the Boys make a Voyage, and he tells them of an Animal that makes itself into a Ship; and of an Insect that builds a Boat, and floats about in a Canoe; and of another that pumps Water, and wears a Mask; and of a Npider that builds a Raft, and floats upon it.

"WELL, boys, I have a most delightful plan for us to-day."

"What is it, what is it, Uncle Philip?"

"Why, I have a little voyage to make, and my boat is on the river just above the mill. I have the men there to row it, and every thing is ready."

"Oh! dear Uncle Philip, this is charming ! we shall be so happy! But-but-"

"But what, boys?"

"Why, Uncle Philip, we have not asked leave at home. Now our parents are very happy to have us visit you, and say that they are very much obliged to you for telling us so 
many things; but they have told us, too, never to get into a boat without asking their permission first. Uncle Philip, we are sure they will let us go, if they know that you are going; only let us run home and ask them."

"My dear boys, I am very much pleased with your conduct; and, what is far better, my children, Gop is pleased; for he has commanded you to honour your father and mother: but you need not go home to ask permission, for you may depend upon it I would not take one of you upon the water without the consent of your parents: so I went yesterday, while you were all at school, and have got permission from your friends for every one of you to go-only I asked them to tell you nothing about it."

"Oh dear, Uncle Philip, you are so very, very good: thank you, thank you, a thousand times over."

"Once is enough, boys. There is but one Being who deserves a thousand thanks, and he, in truth, deserves a great many more than a thousand; but I fear that from a great many he is just the Being who gets the fewest,-it is our Heavenly Father: but come on, boys, let us be going to the boat. We 
shall soon reach her. $\mathrm{Ab}$, yonder she is; I see her through the trees."

"Oh, what a beauty she is, Uncle Philip, with her green sides and white belt near the top. We shall have a charming voyage."

"Come, then ; get in, my little sailors, and seat yourselves yonder in the stern. Now we are all ready; shove off, men, and use your oars. I will take care of the helm."

"Oh, Uncle Philip, how smoothly we go along! this is charming. Is this the way a ship goes, Uncle Philip?"

"A ship floats, boys, just as the boat does; but she is not rowed with oars; she has sails, and the wind blowing upon them sends her along."

"Uncle Philip, there are no ships among animals, are there?"

"Oh no; but there is a very curious little animal which lives in the water, and manages to rig out something like a ship, and to sail."

"What is it, Uncle Philip? pray let us hear of it."

"It is called the nautilus, and I saw a great many of them in the Mediterranean sea. The shell is nearly round, and six or eight inches 
across, not much thicker than paper, and of a whitish colour: it has, too, a keel or ridge upon each side. When it wishes to sail, it stretches upwards two of its legs: these have a very thin skin at the end, which the nautilus spreads out for sails, and the other legs hang over on each side of the shell for oars or rudders. When the sea is calm, a great many of them may be seen playing about; but as soon as a storm arises, or they are disturbed, they take in their sails and sink to the bottom. But, boys, the most curious boat that I know, made by one of the dumb creatures, is the work of the little insect that played the doctor the other day, and stuck his lancet into us. Do you remember what insect that was?"

"Oh yes, very well, Uncle Philip, it was the gnat."

"True, boys, it was the gnat, which is an insect that spends the first part of its life in the water, and the latter part in the air. The grub of the gnat lives in water, and I will give you the whole history of this curious insect. We will first speak of the eggs, for out of these it is that the boat is made. In order to see this boat made, you must go 
early in the morning, between five and six o'clock, to a bucket, or pond of stagnant water, where gnats are to be found: if you go later you will not see it. The gnat's eggs are shaped something like a pocket powderflask, and it is by putting a great many of these together that she makes the boat. To do this, the mother gnat stands by her forelegs upon the side of the bucket, or on a leaf or stick in the pond, and her body is on a level with the water, and rests upon it, except the last ring of her tail, which she raises. a little. She then crosses her two hind-legs in the shape of the letter $X$, and begins to put her eggs in that part of the $X$ nearest to her body. So she brings her legs, crossed in this way, near to her body, and puts an egg in the angle, covered with a kind of glue, which will make the eggs stick together. On each side of the first egg she puts another in this shape $*^{*}$, and here is a drawing of the insect at this part of her work.

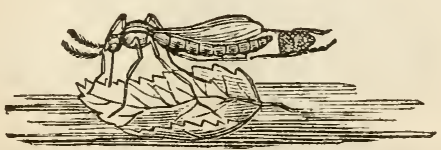

A Gnat making her Boat of Eggs. 
"She then goes on adding eggs, which are all put in the water with their ends downwards, until she has got her boat half-finished; she then uncrosses her legs, and just keeps one on each side of the boat as she goes on, until she has completed it."

"And how many eggs, Uncle Philip, will she put together in this way?"

"From two hundred and fifty to three hundred and fifty, and when all are laid they make quite a good boat, sharp, and raised at both ends, and floating on the water. Then the mother gnat leaves it. Here is a picture of one of these boats.

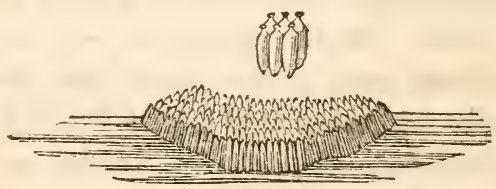

"Now I will tell you of what becomes of the young ones in these eggs. They come out of the lower part of the egg, and commonly swim, with their heads downward, near to the top of the water."

"With their heads downward, Uncle Philip! what is that for ?"

"Why, they have a tube at the end of their 
bodies, near the tail, through which they breathe; and that part must, you know, be at the top to get air. Besides this, its tail and its breathing tube both end in a sort of funnel, made up of hairs placed somewhat in the form of a star, and covered with oil, so as to keep off water, and these buoy or float it up. When it wishes to sink, it just folds up its funnels, and shuts up in them a little bubble of air, which it breathes under the water; and when it wishes to rise, it opens its funnels, and they float it to the top again. Here is a drawing which will show it to you.

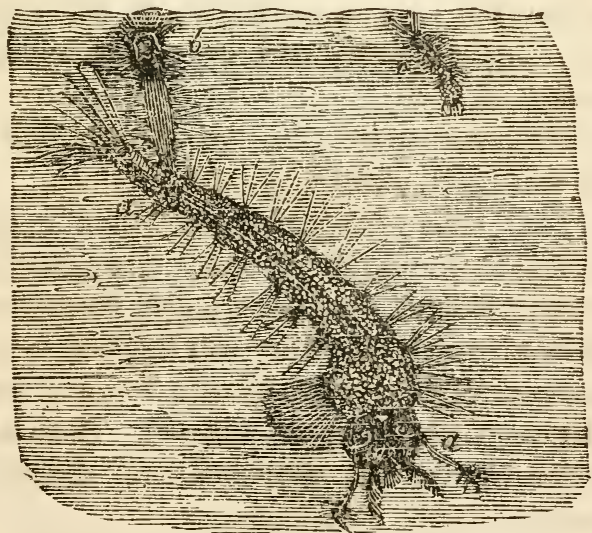

Larva of the common Gnat floating in water, greatly magnified. $x a$, the body and head of the larva; $b$, the respiratory apparatus, situated in the tail; $c$, the larva, not magnified. 
"They are hatched in a few days, and then the boat of empty eggs floats about until it is destroyed by the weather. And to show you how good a boat it is, I will tell you what a gentleman did to prove it. Mr. Kirby, who is very fond of natural history, and has written a great deal about insects, says that he put half a dozen of these gnat-boats in a tumbler half full of water, and then poured upon them a stream from the mouth of a quart bottle, held up a foot above them, and he could not sink them. More than that, the water would not stay in them. If you push one to the bottom with your finger, it will come up to the top directly, and you cannot see any water in it."

"Why, this is a noble boat, Uncle Philip, that will never sink."

"True, boys; but listen, and you will find that before it can use its wings the gnat has to sail in another boat still, much more dangerous than this is. After it is hatched, it has to pass through several shapes before it gets to be such an insect as you see. Here is a picture which will show you its different shapes. 

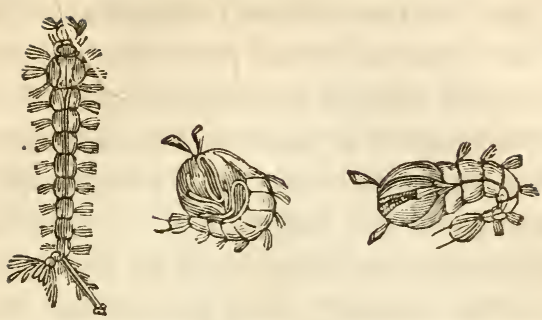

"The first is the same which you saw in the last picture, only in this drawing the head is uppermost. But its last change, when it becomes an insect with wings, is the most curious part of the whole. When it is about to get its wings, and become a perfect gnat, it raises its shoulders just above the top of the water, and its skin cracks, so that the head of the gnat immediately comes through. The shoulders come next, and make the crack larger; but it has yet all its body to get out, and its legs and wings are as yet all shut up in its case. Now is the time of danger for the gnat. It raises itself nearly straight out of the crack, and by wriggling works its body along: and if a particle of water should get upon the case, or touch its wings, it would be overset, and must perish. Thousands and thousands die in this way. It is so very 
light, too, that the wind will drive it about, and whirl it round and round upon the top of the water; and when it is almost out, the insect is tossed about in a canoe or boat of the very weakest sort, while its body is a mast, which appears much too large for so small a boat. At last it gets far enough out of the case to stretch its fore-legs, and put them down upon the water (which will bear a gnat's weight), and then it is safe; it spreads its wings, and soon leaves the little boat which was so dangerous. Here is a picture of the gnat getting out of its case."

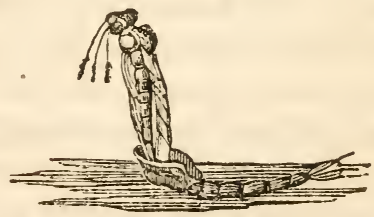

" Well, Uncle Philip, all this is very strange; we never knew before that the gnat was a sailor."

"I suppose that you did not, boys. But as we are talking of boats, pray can you think of any way of making a boat move through water without oars, or paddles, or sails, or something to pull it along?" 
"No indeed.-Oh yes, Uncle Philip, by steam."

"Ah, I mentioned paddles, boys, and a steamboat is forced along by them."

"No; Uncle Philip, we do not know."

"Well, I will tell you then of another way in which I have no doubt a boat might be made to move. If there were any contrivance by which a large quantity of water could be kept in the boat, and if this water were forced out of tubes or holes at one end very violently, it would push against the water in which the boat was floating, and force her along. Some years ago a plan was thought of to make a steam engine throw the water out of the stern of the boat, and thus to force her along; and before that, Dr. Franklin tried some schemes for the same purpose, but they never succeeded. Now there is an insect which adopts precisely this plan, and perhaps some of those who thought of it got the notion from the insect."

"What insect is it, uncle Philip?"

"It is the grub of the dragon-fly. If you catch one of these grubs and put it into a saucer of water with some of the dead leaves or sticks it had for a covering, you will see 02 
these leaves or sticks floating towards the tail of the grub, and afterward driven off again. This is because the insect is pumping in water, and then throwing it out. If you take one of them out of the water, and hold it with its head down, and let a drop of water fall upon its tail, it instantly sucks it in, and you can see it grow larger; and when it throws it out again it becomes smaller."

"But, Uncle Philip, how can you see it suck the water in?"

"Very easily, boys. When it is in the water, if you will colour some other water with indigo, or ink, or any thing else, and then hold a glass tube just over the tail of the insect, and very carefully put some of the coloured water into the tube, you will soon see the grub spirt out a stream of it to the distance of several inches: or if you will put the insect in a saucer of coloured water, and then suddenly move it, and put it into one of clean water, you will see it spirt out the coloured stream plainer still."

"Why, Uncle Philip, it must have a pump inside of it."

"It has, boys, something very like one. This stream of water is forced out to help 
the insect along; for though it has six feet, it uses them very little except for catching food. It drives the water out so strongly against the still water behind it, that it sends it forward, with a dart, very rapidly. Here are two pictures; one shows the pump open, and the other shows it shut."
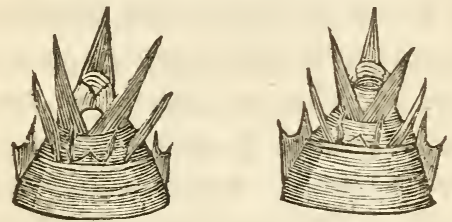

Uncle Philip, is there any thing else curous about this insect?"

"There is, boys, something well worth attention; did you ever see a mask?"

"Do you mean, Úncle Philip, a face made of pasteboard, very frightful commonly, which you can wear over your own face?"

"That is a mask, boys; but so is any thing which is made to wear over the face, and hide it. Now this little insect has a mask, not made like a man's face, but which completely hides its mouth, and it is exceedingly curious." "How is it made, Uncle Philip?" "Why, boys, I am not sure that I can tell 
you, so that you will understand me; but I will try. Suppose your under-lip was horn, instead of being flesh; and suppose it hung straight down until it reached the bottom of your chin, so as to cover the whole of it, and that at the bottom there was a large threesided plate which was hollowed out, and fastened by a joint or hinge to the bottom of your long lip, so that it could turn up on the hinge and cover your face as high up as your nose, and hide your long lip and your mouth and part of your cheeks : suppose, too, that at the upper end of this long face-cover there were two other pieces, so broad that they would cover all your nose and your temples, and could open sidewise like jaws, and show your nose and mouth, so that when they were opened they would appear like the blinders to a horse's bridle; and then suppose that these jaws, upon their inner edges, were cut into a great many sharp teeth, which fitted into each other, and you will have some notion of this curious mask. Do you think you understand me?"

"Why, pretty well, Uncle Philip, we think."

"Well, boys, here are some pictures, and with their help I hope what I have been say- 
ing will be plain enough. In one picture the mask is shut; and in the other, one of the jaws, like a blinder to a bridle, is open. While the

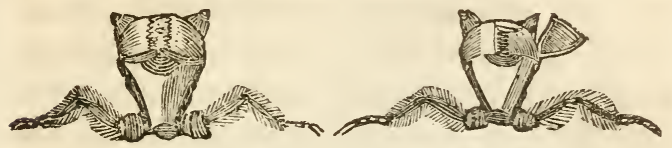

Mask of the Dragon-fly, shut and open.

insect is at rest, it keeps the mask over its face; when it wishes to use it, it unfolds it, and catches its food, and holds it to its mouth. A gentleman once saw one of them holding and eating a large tadpole."

"Uncle Philip, this mask is any thing but handsome."

"Very true; but you know we agreed when we were talking about the bats to look at animals even if they were not handsome. And there is your poor little ugly insect that you thought it right to kill, the spider; did you know that the spider was a sailor, too?"

"No, indeed, Uncle Philip! Pray tell us of it, will you?"

"Yes; but wait a little, until we bring the boat's head right, for we are near the landingplace. So-now, boys, I am ready. There is a very large spider, about which not much 
is yet known, which actually builds a raft, for the purpose of getting its food more easily. You may see it sailing about upon the water, on a ball of weeds about three inches across, which is held together probably by small silk cords spun from itself; and the moment it sees an insect drowning, it leaves the raft, gets the insect, and then returns to eat it at leisure. If you frighten it, or it thinks danger is near, in an instant it is under the raft out of sight." "Ah, this is a cunning spider, Uncle Philip."

"Not half so cunning, boys, as the one we talked of which built a door to its house. But here we are at land. Jump ashore, my lads, and give my respects to your fathers and mothers, when you get home."

"We will. Good day, Uncle Philip."

"Grood day, boys. I shall be glad to see you next Saturday." 


\section{CONVERSATION XIV.}

Uncle Philip tells the Boys about an Insect with Tweezers, and another with Pincers; and shows them how a Fly's Foot is made, so as to stick to the Wall.

"How do you do, Uncle Philip, this morning?"

"Very well, boys, I thank you. You are all well, I suppose, or I should not see you here." "Yes, we are all well, thank you, Uncle Philip. But one of us would be very glad to have your help."

"Why, what is the matter?"

"Charles Walker has run a splinter into his hand, and he wishes you to get it out for him." "Oh, certainly, I will do that, if I can. Let me see : but stay-I must first put on my spectacles. Ah, now I see i: ; I can get it out, but I must take my tweezers to it. There, it is out."

"Uncle Philip, those tweezers are very useful. If you had not had them, you could not have taken hold of the splinter with your 
fingers; and what would you have done then?"

"Tried to cut it out with the point of my penknife; but the tweezers are better for such work; and that reminds me, boys, to tell you that there are insects with tweezers."

"Why, what tool is it that you cannot find among them, Uncle Philip? It really seems as if you found almost every kind among the lower animals."

"Oh, no-no, boys. There are a great many which I cannot find ; but there are several, too, which, as you know, we have discovered."

"And, Uncle Philip, we suppose that men learned to make their tools and work at many of their trades from these dumb creatures."

"Stay, boys-I never said that, because I think that it is not true. We know that in some things men did not learn from the insects, though they might have done so. There is paper, for instance. How could men learn to make it from the wasps, when it was a thing in common use a long time before Mr. Reaumur, of whom 1 told you, found out how the wasp made it? So, too, with a great many tools; men invented them, and afterward, perhaps, it was found out that insects had in. 
struments like them: and at other times the insects did show men how to make some things. I will tell you of one which I think of just now. The city of London, in England, is on the river Thames. Some time since a plan was adopted to make what is called a tunnel under the river. This tunnel is a road dug out of the earth, under the bottom of the river, across it; and of course to keep the water from pressing in the earth as fast as it was hollowed out, it was propped up by walls built on each side, with a very strong arch at the top. The work has now stopped; but about half of it was made. In building this arched road under the water, the workmen used what they called a shield, to keep the water from coming through upon them : and the gentleman who invented it, says that he first thought of it, from examining a little animal named Taret, which will bore holes in large pieces of timber under the water. This little animal has upon its head a kind of shield, by which it keeps off the force of the water, and works without being disturbed. So here was a case in which the insect taught the man."

"Uncle Philip, that gentleman was a sensi$P$ 
ble man, in the first place to watch the Taret and examine its head, and in the next place not to be too proud to learn from it. I expect he was a naturalist ; was he, Uncle Philip ?"

"I do not know, boys; but I should think his discovery of the shield would make him an attentive observer, if he was not so before."

"Now, Uncle Philip, will you tell us of the tweezers?"

"Very willingly, boys. This instrument or tool belongs to the moths which you see flying about at times. The tails are covered with a down, which grows in the form of a thick brush or tuft, and has a shining silky gloss, different in colour from the short hair upon the rest of the body. The moth puils off this hair to cover its eggs, and the tweezers are used for that purpose. Here is a picture of the moths."

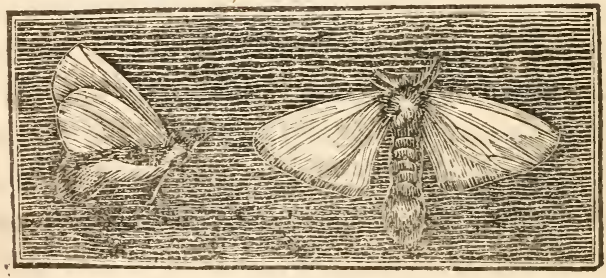

Females of the brown and gold-tailed Moths, showing the bunch of down on the tails. 
"Uncle Philip, you said that the moth pulled this hair off to cover its eggs; are they easily frozen?"

"Not very easily, boys; but you are mistaken in thinking that the moth covers these eggs to keep off the cold; for as she lays them in July and August, and covers them at that time, it cannot be to keep off the cold."

"What is it for, then, Uncle Philip?"

"To keep off the summer heat, boys."

"Why, Uncle Philip! who ever heard of covering a thing up in hair or wool to keep off heat?"

"I have heard of it, and seen it too, boys. It may seem strange, but it is true, that down and wool, and such things, are nearly as good to protect an animal from very great outward heat as they are to keep off very severe cold. When I was at Naples, in Italy, it was summer;--the climate is a very warm one.The country people were in the habit of bringing snow into the city from Mount Vesuvius, and every morning I could see them coming in with their snow, which they sell to the rich to use for cooling things : and they kept it from melting with straw and wool. And in our own country, especially at the south, it 
is very common when a large lump of ice is brought to the house to be used through the day in midsummer, to wrap it up in a thick blanket until it is wanted.

"But I have not yet told you of the tweezers. The moth has no jaws, like bees and wasps, so that it cannot pull off these hairs as the bee would; but, as I told you, it performs the work with its tweezers, which are placed in its tail, and are like the points of a pair of sugar-tongs. The insects, too, will use them very rapidly, and pull off a little of the down, spread the egg upon it, and then cover it with more down, and smooth it very neatly. Here are pictures of these tweezers."
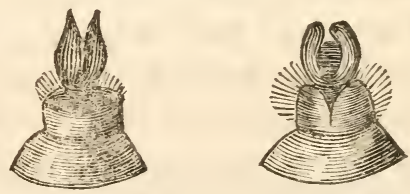

Tweezers of the brown and gold-tailed Moths, magnified.

"This is a curious instrument for the insect to have, Uncle Philip."

"True, boys, but a very useful one. I will tell you, however, of another strange thing concerning moths with their tweezers; I 
mean the way in which they will sometimes place their eggs. The kind of moth that does this work is not exactly known, but naturalists think that the eggs are moth's eggs, because they are covered with the down, exactly like those which are known to be moth's eggs. These eggs are twisted round a branch, like the thread of a screw, or like the curled end of a corkscrew put over a small stick. Here is a picture of some of these eggs."

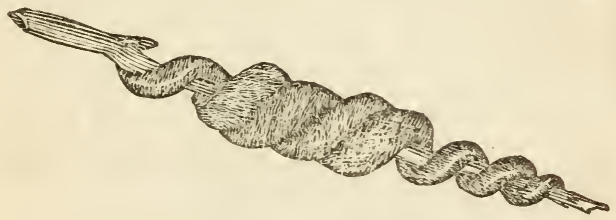

Spiral group of Eggs of an unknown Moth.

"Ah, this is wonderful work indeed for a moth, Uncle Philip."

"As you seem to like this, boys, I will just mention to you that there is another moth, called the lackiey-moth, which winds its eggs also around a branch. They are hard, however, and not covered with any down, and are put on in the strongest possible way. If men wish to make an arch of stone, you know that the stones will be more narrow at the bottom 
than at the top, so that the bottom of the arch may make a small circle, and the top a larger one : thus-
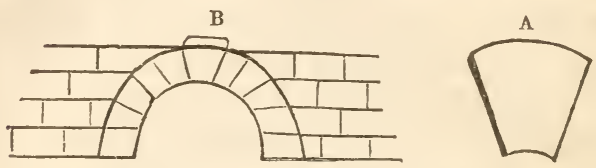

A, Key-stone of an arch; B, Arch completed.

Now the moth goes on this principle. Its eggs are shaped like the bowl of a wine-glass, and the smaller end is put next to the branch. They are all glued together, too, with a kind of gum, which will not dissolve or melt in water; so that the rain cannot injure them. Here is a picture of these eggs.

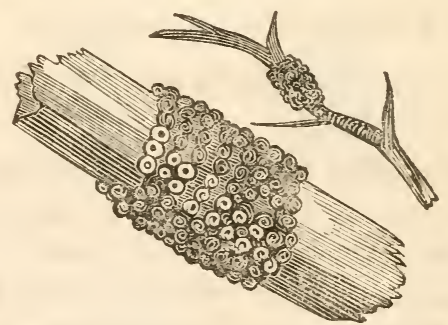

Eggs of the Lackey-moth, wound spirally round a twig of hawthorn; natural size, and magnifled.

"There is another insect, boys, which has something like tweezers; though I think they resemble pincers most." 
"What is it, Uncle Philip?"

"The boys call it father long-legs, and I dare say you have often seen it. It is the crane-fly, and its pincers are used for putting its egg in the hole it has made for it."

"Where does it put its eggs, Uncle Philip?"

"In the earth, boys; and to enable the insect to do this, the female has the pincers I spoke of: they are made of something like horn, and are sharp at the point. With these she first bores a hole in the ground, and then puts the egg in. The egg is like a grain of gunpowder, and she puts herself in a very curious posture to bore the hole. Here, boys, you may see a picture of the pincers as they appear through a microscope, for they

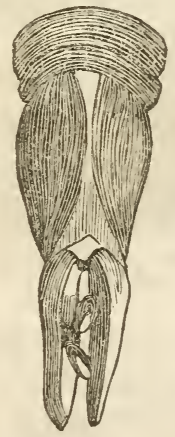

Ovipositor and Eggs of the Crane-fly. 
are not near as large as the picture. And here is a drawing of one boring."

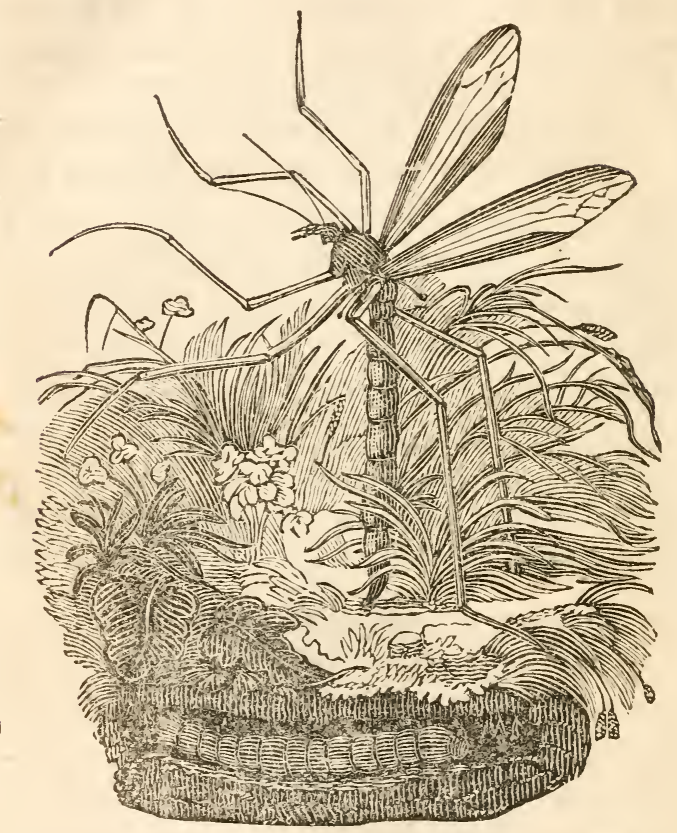

Crane-fly ovipositing, and the larva beneath, in the earth, feeding upon grass roots.

"What good pincers those are, Uncle Philip: but will you tell us one thing which we wish to know? Talking about the crane- 
fly has put me in mind of it: the other day we were sitting together in school, and the wall over our heads was covered with common flies; and when we came out, we were talking about the way in which the fly stuck to the wall without falling down; and as we could not tell what kept him up, we agreed to ask you about it."

"I will tell you, boys, very willingly. I do not wonder that you were unable to tell how the fly stuck to the wall; for you never tried to find out, and therefore could only guess at it." "And that is not a good way to find out any thing, Uncle Philip?"

"No, boys; though some persons much older than you are, did nothing but guess about this very thing, and guessed very far from the truth too. Some thoughit that the fly had a sponge in its foot, and squeezed a sort of glue out of it which made it stick fast; others said that the glass or wall was so rough that the fly's feet would catch hold of the little points upon it ; but both were wrong."

"How does it hold on, Uncle Philip?"

" Did you ever see what the boys call a sucker, made of a piece of soft sole leather? That will show you how the fly's foot sticks 
fast. This leather is cut round, and has a string through the centre; the boys wet it, and then put it upon a board or something smooth, and stamp on it, and try to raise it up from the board by the string; and it requires some strength to pull it up: sometimes they put it on a small smooth stone, and then lift up the stone by it. The reason why the leather sticks so fast is because the air is pressing on it upon the outside, and there is very little or no air between it and the board, to press the other way."

"Why, Uncle Philip, is the air heavy?"

"Oh yes, boys, when there is so much of it as there is above the earth, it presses down very heavily. Now the fly's foot is like the sucker; when he puts it down he has a contrivance to drive out the air from under it, so that there will be little or none between it and the wall; and then the outer air presses upon it, and holds it fast."

"But, Uncle Philip, how does he get it up again?"

"Why, boys, by another contrivance, he can let air in under his foot again, and then he can easily move it; for we do not feel the weight of air when it presses upon both sides 
of us. The reason why you stand up straight is because the air is pressing all around you; if it were on one side of you only, it would press you down on the other side. Here is a picture of the fly's foot, as it appears through the microscope. You will see it has three suckers with the edges all like saws; these are to make it stick the closer. This picture, boys, is sixty-four hundred times as large as the fly's foot is."

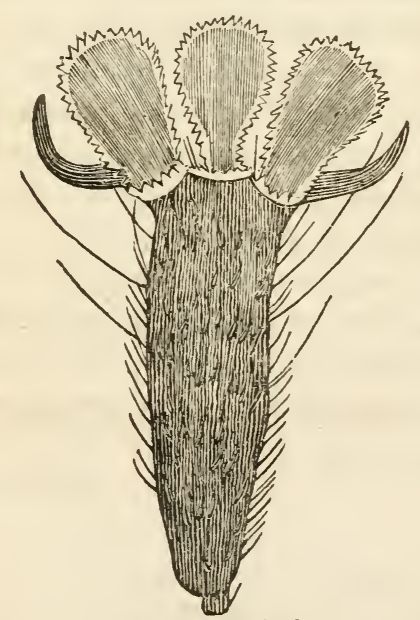

Fly's foot magnified.

"But, Uncle Philip, there is one thing yet hard to understand." 
"What is it?"

"Why, the fly walks on the wall over our heads; now the air cannot press down upon his feet there."

"Very true, boys: it cannot press down, but it can and does press up against his feet; for the air presses up and down and sidewise all alike."

"Ah, now it is plain enough, and we are much obliged to you, Uncle Philip, for telling us what we wished to know."

"You are quite welcome, my dear boys, to all that I can teach you : if it makes you to be wiser and better men when you grow up, I shall be very thankful to GoD that I have been able to do you any good."

"Good morning, Uncle Philip."

"Good day, boys; I shall expect to see you all in church to-morrow."

"We shall be there, Uncle Philip." 


\section{CONVERSATION XV.}

Uncle Philip tells the Boys how Hats are made; and then talks to them about Animals that can make Felt like the Hatter.

"Boys, do you remember my telling you of a remarkable bird, called the tailor-bird, which sews very neatly?"

"Oh yes, Uncle Philip; it is not easy to forget such an excellent little workman; but why do you ask-have you any thing more to tell us about that bird?"

"No, boys, not any thing of that bird; but I was thinking last night of the work done by several other kinds of birds, some of them quite as guod workmen as our little tailor; and I thought that, perhaps, you might like to hear of them."

"We would, Uncle Philip, be very happy to hear of them, if you will have the kindness to tell us about them. But what kind of work is it they do?"

"Various kinds, boys. There are some 
which make what is called felt, just as the hat-maker does; and some are weavers, others basket-makers; some build platforms to live on ; and I assure you some birds' nests are as curious as any of the things of which I have yet told you."

"Pray let us hear of them, Uncle Philip."

"Very well, you shall. I will begin with birds that make felt like the hatter. Do you know how a hat is made?"

"Not exactly, Uncle Philip; but we know what it is made of."

"What is it, boys?"

"Of sheep's wool, and the hair of other animals : is it not?"

"Yes, commonly of these things; and to understand what I am going to tell you, I think it will be necessary first to say something about the hatter's trade. The business of the man who makes a hat is to mix up wool or hair in such a way that it will stick together and make felt; or something like a piece of thick, strong cloth. To do this, he does not weave the hairs together, for they are of different kinds, and of different lengths, and it would be endless work to weave every 
vile III ; besides the cloth or felt would not be thick enough when it was done."

"How do they stick together then, Uncle Philip ?"

"Why, boys, their sticking together is owing to something in the hairs themselves. I will show you. Pull a hair out of your head; now hold it just between the ends of your two fore-fingers, and rub the fingers gently against each other."

"Why, Uncle Philip! see, the hair is moving towards my body."

"Very true; and if you will turn it with the other end towards you, and rub your fingers as before, you will see it move from your body."

"This is very strange, Uncle Philip: the hair is smooth; how can my fingers make it move so?"

"No, that is a mistake, boys, the hair is not smooth. If some kinds of coarse hair are seen through the microscope, each one will seem to be, not one hair, but ten or twelve smaller ones, which are joined at the root, and form a hollow tube, like a straw ; and sometimes it will have joints just like some kinds of grass or straw. In some sorts of finer hair 
you cannot see this even with the microscope; but you can feel it, as you did just now when you moved your fingers. These joints overlap one another, just as if you should take several pieces of straw and stick them into each other. I will show you some pictures of hairs as seen through the microscope, and then these joints will be plain enough."

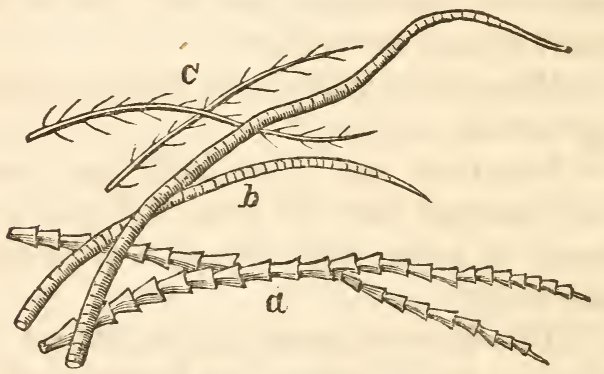

Hairs of $(a)$ the Bat, $(b)$ the Mole, and (c) the Mouse.

"These are strange-looking hairs, Uncle Philip."

"Yes, they are curious; but now you may see why, when hairs are worked together, they may be made to stick to each other. These rough parts catch into each other, and hook themselves; and the more you press them or move them, the more closely you work them 
into one solid mass, which you cannot easily pull to pieces. Besides, you must remember that the hairs will work only one way, as you found out just now when your finger ends caught upon the little joints and moved them along. Now, suppose that a very large heap of hairs, or wool, or fur, after it is made ready, should be put upon a table, and covered with a linen cloth, and pressed down in different directions. Each hair would begin to move in the direction of its root, just as it did between your fingers, and so all would be joined together at last into one solid piece."

"We understand you, Uncle Philip."

"Then you understand, boys, the way in which a hat is made. These hairs are all worked together by the hands of the hatmaker, and to make them work more easily (for curled hair, such as wool, does not move easily) the hatter uses hot water, and dips his hat in it while he is working it. After it is done, $1 \mathrm{t}$ is died, and then put upon a wooden block to give it shape, and is ironed smooth."

"And this is the way, then, Uncle Philip, to make hats : it is curious, is it not?"

"Yes, boys; but plain enough when you come to examine into it. And the best stuff 
for the hatters is such hair as has most joints ready to catch into each other: the rabbit's hair is very good, and for that reason."

"And is it possible, Uncle Philip, that any bird can do such work as this ?"

"Not only possible, boys, but true. There are several birds very expert at making felt, and their nest appears like a piece of hatter's felt, or double-milled woollen cloth. I do not mean to say that it is as close and solid as the hat or cloth; it would feel in your fingers looser than either, still it is quite close; and when you examine it, you will find it put together in the same way; it is all carded into one mass, and not woven together thread by thread, or hair by hair."

"And are there many birds able to do such work, Uncle Philip?"

"I told you, boys, that there were several. The chief article which they use is wool, but with this many other things will be found mixed-sometimes, upon the outside, fine moss-sometimes pieces of a spider's web rolled up into a little bundle--sometimes, when cotton can be had, they will use small bunches of cotton-wool ; but sheep's wool they must have, and by means of that, they contrive to make, 
with the other things I have mentioned, a felt wonderfully smooth."

"Is it smooth on the outside, Uncle Philip?"

"Sometimes quite so; but always as smooth on the inside, when it is first made, as if it had been felted together by the hat-maker. There is another thing curious enough in some of these nests. The hatter, you know, binds the rim of his hat to make it stronger; and some of these felt-making birds will make their nests stronger by a binding all around them of dry grass stems, and sometimes of slender roots, and they take care to cover these grass stems, or roots, with their felt-work of moss and wool. But there is something else not less strange, I think, than the binding. It is this : they will build their nests in the fork of a shrub or tree; and to keep them from falling, they will work bands of this felt round all the branches which touch the nest, both below and at the sides. And those parts of the nest which touch the large branches are always thinner than the other parts, which have no support; in those parts the nest is nothing but a thin wall of felt, fixed around to fit the shape of the branch, and that is enough to 
make that part of the nest warm and soft. Here is a picture of one of these felt-nests, fastened in the way of which I have been telling you.

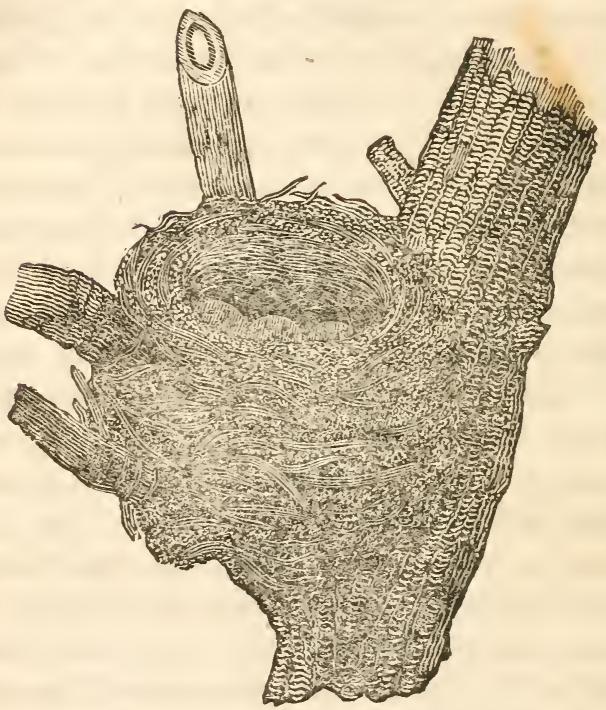

Chaffinch's Nest on an Elder-tree.

"This, boys, is the nest of the chaffinch. The goldfinch makes a nest of the same kind, only rather neater and smoother than that of 
the chaffinch; for it takes pains to show nothing but the wool, and covers up all the other materials which it uses."

"Uncle Philip, do these birds all use the same things to make their nests?"

"All use wool, boys; but the truth is, that birds will commonly take for their nests that article which they can get most easily, if it will suit. A gentleman, named Bolton, tried this with some goldfinches. He saw a pair of these birds beginning to build in his garden; they had laid the foundation of their nest with moss, and grass, and such things, as they commonly use : he scattered some wool about in different parts of the garden; the birds took the wool: afterward he scattered cotton; they took the cotton: on the next day he gave them some very fine down; they took that, and finished the nest with it, and a very handsome nest it was."

"How long were they in making it, Uncle Philip?"

"Three days. The canary-bird, boys, which you sometimes see in cages, when free, builds a nest of the same kind. But the most curious felt-makers among the birds, are in 
Africa. There is the Cape-tit, a bird in the southern part of Africa, which builds a very strange nest: it is shaped like a bottle of India-rubber, as thick as a coarse worsted stocking, and made of cotton, and down, and other things felted together. On one side of the nest there is something like a pocket, and here is a picture of it."

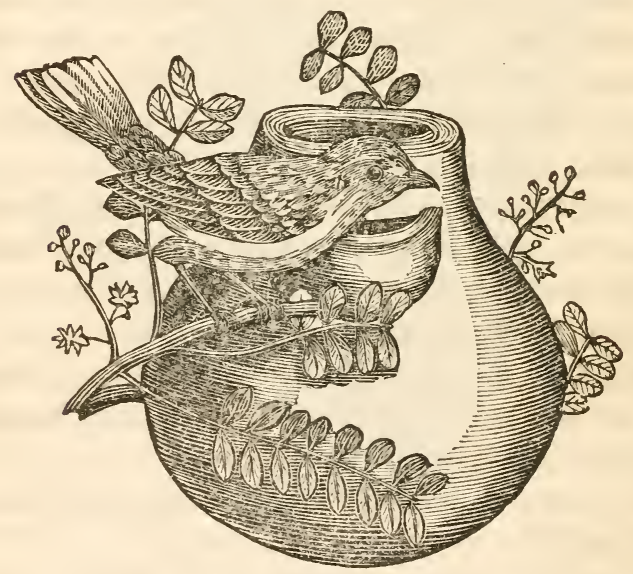

Nest of the Cape-tit, from Sonnerat.

"Uncle Philip, what is that pocket for?"

"Why, boys, some have supposed that it 
was for the male bird to sit on and keep watch, while the female was inside of the nest sitting on the eggs; but I think this is a mistake. And some have said, that when the female leaves the nest, and the male wishes to go too, he sits in this pocket, and beats against the side of the nest with his wing until he has made the edges of the top meet, and thus shuts up the mouth of the nest, and keeps off insects and other animals that would eat the young ones; but I do not believe this story."

"Then what do you think the pocket is for, Uncle Philip?"

"I think, boys, that it is nothing but a perch, or place for the bird to sit on before going into the nest. If the bird had no such place for stopping, it might be troubled to get into its nest. The mouth is small, and the bird could not enter it with its wings spread; and if it should alight on the edge of the nest constantly, it would injure it, for it is but slightly made. And I will tell you another reason why I think this is the use of the pocket. There is another bird in South Africa, called the pinc-pinc, which is the same species of bird as the Cape-tit; and this bird we know uses its little nest built upon the side 
of the other merely as a resting-place before going into the nest."

"Uncle Philip, does the pinc-pinc build its nest like a bottle, as the Cape-tit does?"

"No, boys, not so smooth, but felted in the same way. The nest is made mostly of the down of plants, and is either snowy white or brownish, according to the colour of the down. On the outside it is a clumsy-looking thing, but fastened, like the nest of the chaffinch, very firmly to the branches near it, so that you cannot take it away without breaking it to pieces. But rough as the outside is, you would be astonished, if you were to look at the inside, and see how a bird, and a small one too, with nothing but its wings, and tail, and feet, and bill for tools, could ever have worked the down of plants together, so as to make of it a piece of fine cloth. It has a narrow neck, something like a chimney, at the top of it. This is the entrance; and at the lower end of it there is a lump, which appears something like a small nest stuck on to the larger one; sometimes there will be three or four of these smalllooking nests, and sometimes when there is a branch near the mouth of the nest which makes a good resting-place, there will be 
none. Here is a picture, boys, of the outside of one of these nests. These birds are easily

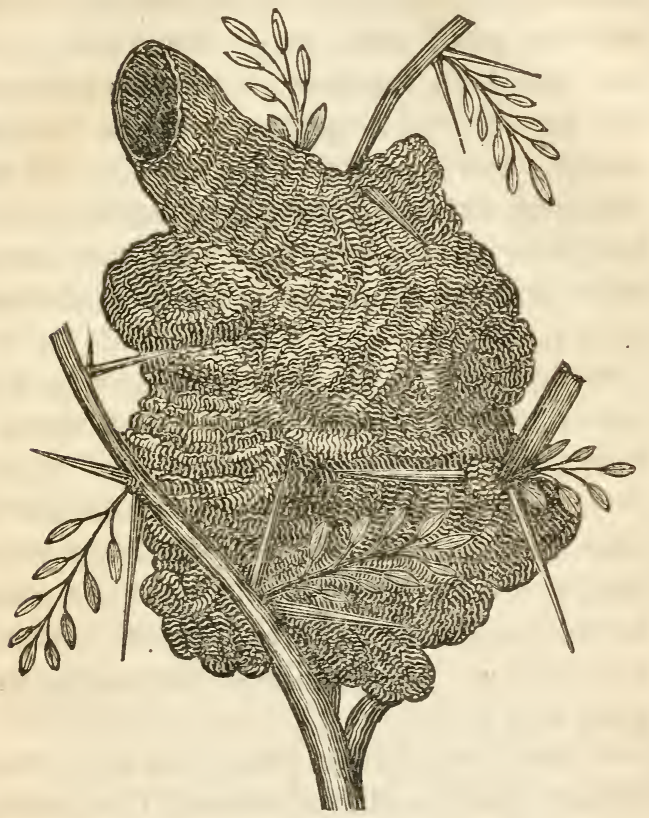

Nest of the Pinc-pinc.

watched; and a French gentleman, who has written the best account of the birds of Africa, ${ }^{*}$

* M. Vaillant. 
says that he has found at least a hundred of these nests, and watched the birds for a whole morning together, and never saw one sitting on the small nest as a watch-bird; but has seen both the male and female arrive at the nest together, perch upon the nearest branch, hop from this upon the edge of the little nest, and then putting their heads into the hole, dart into the large nest. And now, boys, what do you think about the use of these little pockets?"

"Oh, Uncle Philip, we think that what you tell us is always right, because you know a great deal more than we do."

"But, boys, you do not understand me. I may be mistaken, though I do know more than you. I have been telling you my reasons for thinking these little pockets are nothing but perches. Do you think the reasons are good ones ?"

"Why, yes, Uncle Philip, we do. The French gentleman who watched the birds so much would have seen some of them using the pockets for a place to keep watch in, if they were made for that."

"Right, boys. What I wish to teach you is to think for yourselves. Whenever any 
one gives you a reason for a thing, just ask yourselves, "Is this a good reason?'"

" But, Uncle Philip, how did it happen that the other people who saw these birds should have said that these pockets were for the male bird to sit in and watch?"

"I suppose, boys, that they really thought so; but then they had not noticed the birds enough to find out the truth. It requires a great deal of time and patience to find out the truth about animals : and this is the reason why so many mistakes have been printed about them. It is a pity that such mistakes have been made; for really there is enough that is very curious about them, without men's making stories to appear strange. But I think that there will be fewer mistakes made in future."

"Why so, Uncle Philip ?"

"Because, boys, men are taking more pains to see for themselves. There are more naturalists now than there were formerly; and I hope there will be more still, especially in our own large and beautiful country, where there have not yet been many. I hope that natural history will be studied in all our schools be- 
fore a great while. But let us go back to our African birds.

" There is another kind which Mr. Vaillant speaks of, and I will tell you of that. He calls it the capocier, and he had a very fine opportunity to watch two of them. It is a bird easily made gentle, and he had managed by feeding two of them to make them so tame that they would come into his tent and hop about several times in a day, though he never had them in a cage. When it became time for them to build a nest, they staid away for some time, and would come to the tent once only in four or five days. At last they began to come regularly, as before, and Mr. Vaillant soon found out what they came for. They had seen upon his table cotton and moss and flax, which he used to stuff the skins of birds, and which were always lying there; and the capociers had come for these things, to build their nest of them. They would take up large bunches of them in their bills and fly away. Mr. Vaillant followed and watched them to see the nest built, and found them at work in the corner of a garden, by the side of a spring, in a large plant which grew under 
the shade of a tree. They were building in the fork of the branches, and had laid the foundation, which was about four inches high and six inches across. This part was made of moss and flax, mixed with grass and tufts of cotton. The next day this gentleman never left the side of the nest: the female was at work building, and the male brought the materials. In the morning the male bird made twenty-nine journeys to Mr. Vaillant's table for flax and cotton and moss; and in the afternoon he made seventeen. He would help his mate to trample down and press the cotton with his body, so as to make it into felt. Whenever he came with a load, he would put it either upon the edge of the nest or upon some branch within reach of the female.

"After he began to help the female at her work, he would often break off, and begin to play; and sometimes, as if in mischief, he would pull down a little of her work. She would get angry, and peck him with her bill ; but he still continued to vex her, until at last, to save her work from being pulled down, she would stop working, and fly off from bush to bush, to tease him. They would then make up the quarrel, and she set about her 
work, while he would sing most delightfully for several minutes. After his song was finished, he would go to work again, until he got into a new fit of mischief and frolic, and then he would torment her as before.

"On the third day the birds began to build the walls, after having repeatedly pressed the bottom, and turned themselves round upon it in all directions, to make the nest solid. They first made a plain border all around; this they trimmed, and on it they piled up tufts of cotton, which they felted in by beating and pressing with their breasts and wings; and if any part stuck out, they worked it in with their bills, so as to make all perfectly smooth and firm. And they worked their nest round the branches near it, just as the chaffinch does.

"In seven days they finished it. It was as white as snow, and on the outside it was nine inches high, and not smooth or regular in its shape; but in the inside it was shaped exactly like a hen's egg, with the small end up: the hollow was five inches high, and between four and five inches across; and it was so neatly felted together that it might have been taken for a piece of fine cloth a little worn; and so close that you could not take away 
any part without tearing the nest in pieces. Here is a picture of the nest, boys, and it is wonderful work for a small bird."

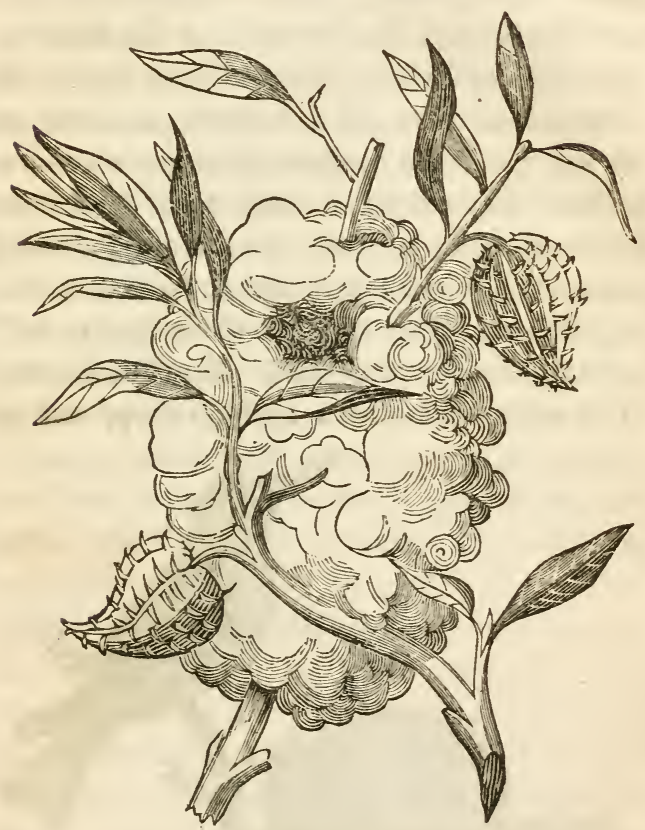

Nest of the Capocier, from Vaillant's figure.

"Oh, Uncle Philip! we like the capociers very much. When they were tired of work- 
ing, they were ready to play; and when they had played enough, they went back to work. Do not you think there was good sense in that?"

"Yes, boys, I do: it will not do, either to work all the time or to play all the time. All that we have to do is to take care that we do not spend more time than we should at either. But there is a sweet little bird, boys, quite common in our own country, which makes felt : would you like to hear of it ?"

"Oh yes, Uncle Philip. What bird is it?"

"It is the humming-bird. Here is a drawing of its nest. It is about an inch deep, and an

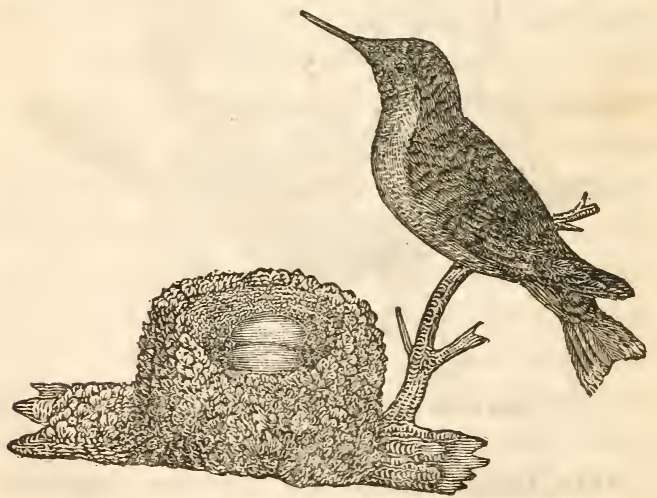

Nest of the Humming-bird. 
inch across ; and from a little distance, appears more like a small knot upon the branch than like a bird's nest. 'The outside of the nest from which this picture is made, was covered with a kind of bluish-gray lichen, that grows in scales upon old trees and fences: this seemed to be glued on by the bird in some way or other. The inside was the felt, and was made of the fine down from seeds that float about in the air, mixed with the down from mullein-weed and stalks of fine grass. This, boys, is the smallest nest made by a bird, I believe ; and some insects make larger houses for themselves than this bird does.

"But I have not time at present to talk with you any longer, as I have letters to write; and therefore I must bid you good morning."

"Farewell, Uncle Philip." 


\section{CONVERSATION XVI.}

Uncle Philip tells the Boys about Birds that are Weavers; and about the Politicianbird; and a Story about some Philosophers; and what may be learned from these Conversations.

"Well, boys, were you pleased enough with our last conversation to wish to hear more about birds' nests?"

"Yes, if you please, Uncle Philip. You said something about birds that were weavers ; we should like to hear something of them."

"Very well, then; I will talk about the weavers this morning. And the first thing I have to say is that this is no uncommon trade among birds. Take the nest of any of the common small birds that use hair for a lining, and you will be apt to find some part of it woven."

"But, Uncle Philip, you do not mean that 
birds weave as smoothly and regularly as people do !"

"Not quite, boys; but still it is very fair weaving, and done as our weaving is, by working a hair or thread in and out between other hairs and threads, or roots, or bits of stick and grass. The best way to see it, is to remove the outside work of hay or roots very carefully, or to take away the felt-work of wool or moss, and you may see a round piece of hair-cloth, sometimes finer, and sometimes coarser, according to the bird that made it, and the things of which it is made. In the common sparrow's nest the hair-cloth is very thin, so that you can see through it easily; but still every hair is woven in singly, and always bent, so as to lie smooth in the bottom of the nest. And there are no ends of hairs left sticking out; they are always worked into the moss which makes the outside of the nest."

"Uncle Philip, how do the birds make the hairs lie smooth in their places?"

"About that, boys, there is some uncertainty. Some persons think that the birds have a kind of glue in their mouths by which they make them stick; and others suppose 
that they wet the hairs, so as to make them bend. But there are much better weavers than the common sparrow. The red-breast and the yellow-hammer are both better workmen."

"Where do they get hairs, Uncle Philip ?"

"They find bunches of them sticking in the cracks of a fence or post where a horse or cow has been rubbing; and some of these little creatures, when they find such a bunch, will pull it to pieces, and work it in, hair by hair."

"Are there many of these weaver-birds, Uncle Philip?"

"Yes, boys, a great many : our country is quite full of them. There is the mountain ant-catcher, ${ }^{*}$ which will weave a nest of dry grass, and wind the blades round the branches of a tree; and the king-bird, $\uparrow$ which first makes a basket frame-work of slender sticks, and afterward weaves in wool and tow, and lines it with hairs and dry grass. There is another, too, the white-eyed fly-catcher, which some have called the politician. This bird builds its nest and hangs it up by the upper edge of the two sides on a vine. The outside is made of pieces of rotten wood, threads of

* Myiothera obsoleta of Bonaparte.

$\uparrow$ Tyrannus intrepidus. 
dry stalks or weeds, pieces of paper, commonly old newspapers; and all these are woven together with caterpillar's silk, and lined with fine dry grass and hair."

"Uncle Philip, why do they call it the politician? What is a politician?"

"What is commonly called a politician, boys, is a person who is always reading in newspapers about the government of the country, and talking a great deal about the President and Congress, and the laws that are made, and all such things: but the real politician is one who studies the different kinds of government which have been in the world, and endeavours to find out which is good and which is bad, and why they are good or bad. He reads, too, a great deal of history, to learn how other nations have done, what kind of laws they made, and why they made them, how they became great nations, or how they became very poor; and he thinks, too, a great deal, that he may find out what will be best for his own nation. It requires hard study and thought, boys, to make a good politician."

"Then, Uncle Philip, a man cannot learn how to be one out of the newspapers."

"No, boys; not out of newspapers alone: 
but still he will read them, and very often learn from them things very useful to him in his business. Newspapers are valuable things, and I think it is always best for a country to have a great many of them spread about in it. But they will not, of themselves, maki a man a politician ; and if you should ask the persons who print them, whether they expect them to teach men all about governments, they will tell you, No: but they will teach people what is doing in all the governments in the world. No good government, boys, will ever be afraid to let the people have newspapers. They are always ferwest where the government is hardest upon the people. But let us go back to the birds. Can you tell me now why some people call the fly-catcher a politician?"

"Oh, yes ; because he has so many bits of old newspapers about his nest."

"That is the reason, boys. There is another kind of fly-catcher, called the hooded fly-catcher, and it weaves its nest of flax and strings pulled from the stalks of hemp: but the best weaver in this country is the Baltimore starling. This bird chooses the ends of high bending branches for his nest, and he begins in a forked twig, by fastening strong 
strings of hemp or flax around both branches of the fork, just as far apart as he means the width of his nest to be: he then with the same kind of strings, mixed in with pieces of loose tow, weaves a strong, firm kind of cloth, which is like che hatter's felt in appearance, only that you can see that the nest is woven, not felted. In this way he makes a pouch, or purse, six or seven inches deep, and lines it on the inside with several soft things, which he weaves into the outside netting, and finishes the whole with horse-hair. Mr. Wilson describes one of these nests which he had. He says that it was round like a cylinder. Do you know what a cylinder is?"

"No, Uncle Philip."

"A smooth round pillar to hold up a porch is a cylinder; my walking-cane is a cylinder; so is the straight body of a tree. When these are of the same size all through their whole length, they are perfect cylinders; and any thing in that shape is a cylinder."

"We understand you, Uncle Philip; a gunbarrel is a cylinder, and there is a cylinder in your garden."

"What is it?"

"The heavy stone roller that you let us pull over the walks.". 
"Right. Well, this nest was like a cylinder, about five inches across, and seven inches long. At the top the bird had worked a level cover, so as to leave a hole only two inches and a half across ; at the bottom it was round. It was made of flax, tow, hemp, hair, and wool, and was woven into a complete cloth; it was also tightly sewed through and through with long horse-hairs, some of which when drawn out measured two feet. Here is a picture of this

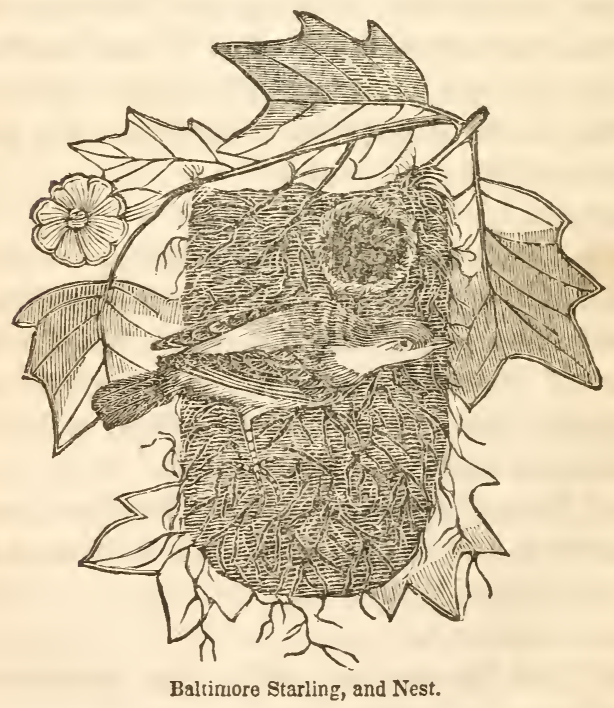


nest. In the bottom it had bunches of cows' hair, and these were also sewed down with horse-hairs. This bird, boys, is a thief."

"A thief, Uncle Philip! What does it steal ?"

"When I say it is a thief, boys, I mean that it takes what does not belong to it: but it is not a thief as man is. When a man takes something which belongs to another person, he linows that it is not his; and therefore he steals : but the poor bird does not know, and that makes a difference. You asked me what it steals: I will tell you. At the time for building its nest, it will take whatever suits for that purpose; and therefore the country wornen are obliged to watch their thread that they have put out to bleach : the farmer, too, who has cut off young grafts from his fruittrees and tied them up in bundles, must be careful, or the bird will pull at the string till he gets it off; and sometimes, when the bunch is not too large, he will fly off with the whole. In autumn, when the leaves have fallen, you may sometimes see skeins of silk and hanks of thread hanging about the starling's nest, but so woven up and entangled in it that they are good for nothing. Now, boys, before this 
country was settled by people from Europe, where do you suppose the starling got silk and thread for his nest?"

"Why, Uncle Philip, are you sure he got them at all ?"

"A very sensible question, boys. When you are asked why a thing is so, it is always well, first to be satisfied that it is so, before you begin to look for a reason. I have read a story about this very thing: would you like to hear it?"

"Oh yes, Uncle Philip."

"Well, then, I have read that there were once several philosophers (I told you what a philosopher is, you know), who were in the habit of meeting together to put questions to each other, and to make new discoveries. At one of these meetings, one of them asked the others, ' Why a fish weighed more $i n$ the water than he did out of it?' Several of them gave very wise reasons, as they thought; and all the reasons were different: so they could not agree. There was among them, however, a very sensible old gentleman, who listened to them all, but said nothing. When he went home, he got a fish and weighed it, out of the water, and wrote down its weight; he then 
took a bucket of water, and weighed that ; and when he dropped the fish in the bucket, he found that it increased the weight of the whole, precisely as many pounds as the fish had weighed out of the water; so he found out that there was no reason why a fish weighed more in the water than he did out of it, because it was not true: his weight was the same either in or out of it."

"Ah, Uncle Philip, that is a pleasant story: he was a sensible old gentleman."

"Yes, boys, he was; and it was sensible in you to ask first whether the starling did use silk and thread before Europeans came here ; and after that is answered, it is time enough to ask where he got such things. Now the truth is, that he did not use them until after Europeans brought them here; because there were no such things in this country: for the Indians who lived here could not make thread, I think; and I am sure they could not spin silk: but I will tell you, boys, what it shows us ; and it is that I wish you to notice."

"What is it, Uncle Philip ?"

"It is the wisdom of this bird in taking advantage of circumstances. No doubt he built very good nests long before silk and thread 
were in the country; but he had sense enough to know that they were exactly what suited him, and he used them as soon as he could get them."

"Then, Uncle Philip, you think that the bird has reason?"

"No, boys, I do not: but you have reason, and I have something to say to you about it. It is this: as Goo has given you reason, and so made you better than the poor dumb animals, he expects more from you. That is fair, is it not?"

"Yes, Uncle Philip ; very fair."

"Then what I wish you to remember is this: that you must use your reason in such way as to glorify Goo. He gave it to you to learn his will and his commandments, and to live accordingly. So now you see the things which our conversations about the animals can teach us. In the first place, we see the goodness of God; in the second place, we see the power of God; in the third place, we see the wisdom of God: and we see in ourselves that God has done more for us than he has done for them, and therefore we ought to love and serve him: we ought to believe what he says in his Word; we ought to pray 
to him for his blessed help; we ought, first of all, to seek the salvation of our souls, through our Lord Jesus Christ.

"Now, my dear children, to-morrow I must leave home for a few weeks ; but when I come back we will talk together again: and as I am going to see my nephews, I will get a book which they printed about insects; it is called the History of Insects, ${ }^{*}$-and I will bring it to you; and some of the largest boys among you may read it aloud, and I will explain to you what you cannot understand. If you are pleased with what $I$ have been telling you, that book will tell you a great deal more."

"Oh, thank you, Uncle Philip. We shall like it very much."

"Farewell, boys."

"Good-by, dear Uncle Philip."

* Family Library, No. VIII.-Publishers.

THE END. 

Now republishing, on good paper and large type, in 18mo. volumes,

\section{S O C I A L E V I L S. \\ AND}

\section{THE I R R M E D Y.}

A SERIES OF NARRATIVES TO BE PUBLISHED QUARTERLY.

BY THE

REV. CHAR LES B. TAYLER, M.A.

\section{No. I. \\ TXI IMECIANIC.}

IS NOW REPUBLISHED, AND FOR SALE BY THE BOOKSELLERS.

"Other foundation can no man lay than that is laid, which is Jesus Christ."

\section{AUTHOR'S ADDRESS.}

No doubt can be felt as to the fact, that there are at present. many crying evils in all ranks of society-perhaps there never was a time when more remedies were proposed. It is, however, a melancholy truth, that the only remedy is too generally overlooked, or despised. Remedies, selfish in principle, and selfish in their proposed end, are held forth and confided in by those who profess to be Christians, and, as such, dependent on the Great Head of the church. Man is taught how to live in time, and to be wise for time; but it has become unusual to refer to that, fine old scriptural prayer, "So teach us to number our days that we may apply our hearts unto wisdom." Indeed, the wisdom desired by too many is that which is so forcibly described by an apostle's pen, as "earthly, sensual, devilish ;" not that wisdom the attributes of which form the graces of man's new and regenerate character, which is first pure, then peaceable, gentle, and easy to be entreated; "full of mercy and good fruits, without partiality, and without hypocrisy."

It is intended, in the series of narratives now advertised, to set forth, faithfully and simply, the one great principle on which Christians profess to act. This principle should never be lust 
sight of, in any publication addressed by a Christian author to Christian readers. "Other foundation can no man lay, than that is !aid," laid by Infinite Wisdom himself-" which is Christ Jesus." My illustrations will extend to every class of society ; from the highest to the lowest. When it is found necessary to introduce the subject of political economy, I shall endeavour to give what scem to me the right views of the subject; and I shall take care to show, that whell political economy cannot be identified with Christian economy, it ought to occupy a subordinate place. If it enters society as the servant of Christian principle, it may be very useful as a servant; but, if it is to teach a man to walk in the counsel of the ungodly, to speak of its usefulness in a Christian community is absurd.

False principles, however taking they may be, for a while, with the ignorant, or with those who are not deep thinkers, can never stand for any length of time; and as for the ungodly, we know Who has told us they are "like the chaff which the wind driveth away." I have undertaken this work in a spirit of prayer to God for His assistance, and His blessing. Many of my readers, I ain sure, will unite their prayers to mine, that it may be continued in the same spirit. Some few may object to this address from a minister of Christ to a Christian community, and say that it is according to the puritanical cant of the day. 1 answer, that such cant (if mere cant) is quite as offensive to me as to themselves; almost as offensive as the cant of ungodliness; but I cannot forget those words of solemn warning, from One who, alas, is still the despised and rejected of many men: "Whosoever shall be ashamed of me and of my words, in this adulterous and sinful generation, of him shali the Son of man be ashamed, when he cometh in the glory of his Father with the holy angels."

The second number of "Social Evils," entitled " The Lady and the Lady's Maid," will be republished about the lst of February, 1834 .

\section{THEOLOGICAL LIBRARY.}

No. I. The Life of Wiclif. By Charles Webb Le Bas, A.M.

II. The Consistency of the whole Scheme of Revelation with Itself and with Human Reason. By Philip Nicholas Shuttleworth, D.D.

III., IV. Luther and the Lutheran Reformation. By John Scott, A.M.

V., VI. The Life of Archbishop Cranmer. By Charles Webb Le Łas, A.M.

VII., VIII. Historl of the Reformed Reigion ln Franch. Bv Rev. Edward Smedley, M.A. In Press. 





